\title{
Heeft Champost waarde als biobased product?
}

J.J.P. Baars \& A.S.M. Sonnenberg

Plant Research International, onderdeel van Wageningen UR

Business Unit Plant Breeding 
(C) 2015 Wageningen, Stichting Dienst Landbouwkundig Onderzoek (DLO) onderzoeksinstituut Plant Research International. Alle rechten voorbehouden. Niets uit deze uitgave mag worden verveelvoudigd, opgeslagen in een geautomatis eerd gegevensbestand, of openbaar gemaakt, in enige vorm of op enige wijze, hetzij elektronisch, mechanisch, door fotokopieën, opnamen of enige andere manier zonder voorafgaande schriftelijke toestemming van DLO.

Voor nadere informatie gelieve contact op te nemen met: DLO in het bijzonder onderzoeks instituut Plant Research International, Plant Breeding.

DLO is niet aans prakelijk voor eventuele schadelijke gevolgen die kunnen ontstaan bij gebruik van gegevens uit deze uitgave.

Exemplaren van dit rapport kunnen bij de (eerste) auteur worden besteld. Bij toezending wordt een factuur toegevoegd; de kosten (incl. verzend-en administratiekosten) bedragen $€ 50$ per exemplaar.

Plant Research International , onderdeel van Wageningen UR Business Unit Plant Breeding

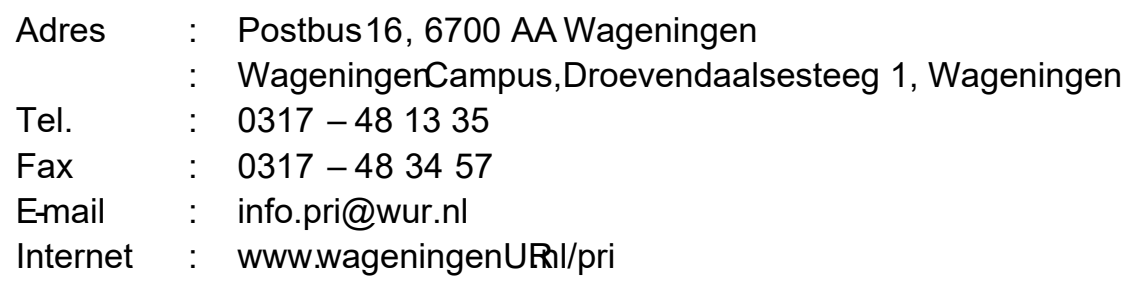




\section{Inhoudsopgave}

pagina

1. Samenvatting 1

$\begin{array}{ll}2 . & \text { Inleiding }\end{array}$

3. Testen van schimmelgroei op champost $\quad 5$

3.1 Gebruikte champost 5

3.2 Gebruikte schimmels tammen 5

3.3 Geteste substraten 5

3.3.1 Groei op champost $\quad 5$

$\begin{array}{lll}3.3 .2 & \text { Groei op mengsels van champost } & 6\end{array}$

$\begin{array}{lll}3.4 & \text { Discussie } & 7\end{array}$

4. Toegankelijkheid cellulose en hemicellulose na behandeling van champost met schimmels 9

4.1 Effect doorgroeiing van champost met witrot schimmels op het lignine-gehalte. 9

4.2 Vermogen van witrot-s chimmels om cellulose in champost beschikbaar te maken voor enzymatische $\begin{array}{ll}\text { afbraak. } & 9\end{array}$

$\begin{array}{llr}4.3 & \text { Discussie } & 10\end{array}$

5. Champost als bron van enzymen 12

5.1 Maken van een enzymextract. $\quad 12$

5.2 Bepalen van de enzymactiviteit $\quad 12$

$\begin{array}{lll}5.2 .1 & \text { Cellulase activiteit } & 12\end{array}$

$\begin{array}{lll}5.2 .2 & \text { Hemicellulase activiteit } & 13\end{array}$

$\begin{array}{lll}5.3 & \text { Discussie } & 14\end{array}$

6. Champost als substraat component in de teelt van koningsoesterzwam (Pleurotus eryngii) 15

6.1 Karakterisatie van de gebruikte champost. 15

$\begin{array}{ll}6.2 & \text { Substraatsamenstellingen } \\ 6.3 & 15\end{array}$

$\begin{array}{lll}6.3 & \text { Teeltverloop } & 16\end{array}$

$\begin{array}{lll}6.4 & \text { Conclusie } & 18\end{array}$

$\begin{array}{lr}\text { 7. Geciteerde literatuur } & 20\end{array}$

Bijlage I. Meetgegevens teeltproef met champost als vervanger voor zaagsel. 1 



\section{Samenvatting}

Dit rapport beschrijft de resultaten van onderzoek naar de vraag of Champost waarde heeft als biobased product. Dit onderzoek was onderdeel van een groter project met de titel "Increasing utilization of organic waste and low value feeds with the help of lignin degrading fungi".

Champost heeft als globale samenstelling $359 \mathrm{~kg}$ droge stof per ton versgewicht. Deze $359 \mathrm{~kg}$ droge stof bestaat voor ongeveer $138 \mathrm{~kg}$ as en voor ongeveer $222 \mathrm{~kg}$ uit organische stof. Deze $222 \mathrm{~kg}$ organische stof bestaat uit ruwweg $56 \mathrm{~kg}$ lignine, $54 \mathrm{~kg}$ cellulose en $4 \mathrm{~kg}$ hemicellulose. De overige $108 \mathrm{~kg}$ droge stof is wateroplosbaar. Precieze verhoudingen tussen deze componenten van champost kunnen van batch tot batch vers chillen.

De hypothese is dat het lignine de cellulose en hemicellulose in de champost beschermt tegen afbraak door de champignon. In het onderzoek is geprobeerd of champost gekoloniseerd kon worden door witrot schimmels die goed in staat zijn om lignine af te breken. De witrotschimmels zouden daardoor (een deel van) de resterende cellulose en hemicellulose beschikbaar kunnen maken voor nieuwe toepassingen.

Typische witrotschimmels zoalsPleurotus erygii, Pleurotus sajoxaju, Trametes suaveolensTrametes versicolor, Clitocybula dusen,iiGymnopilus sapineuen Bjerkandera adustazijn in staat om uit (gesteriliseerde) champost nog voldoende veding te halenvoor vegetatievegroei. De witrotters Lentinula edodesn Ceriporiopsis subvermisporæen de schimmelsStropharia rugoscannulatæn Lepista nudableken niet in staat te groeien op champost. De schimmels die op (gesteriliseerde) champost konden groeien waren in staat othigreinegehalte in champost te verlagen. Onbehandelde champost had een ligninegehalte van ongeveer $32 \%$. Pleurotus eryngii was in staat om het ligninegehalte te verlagen tot $21 \%$. De overige schimmels lieten een kleinere verlaging van het ligninegehalte zie.

De toegankelijkheid voor enzymen van het cellulose en hemicellulose na behandeling met schimmels werd getest met pensmicroorganismen. De micrørganismen in de pens zijn efficiënte afbrekers van cellulose en hemicellulose, maar ze zijn niet in staat olignine af te breken. De hoeveelheid cellulose en hemicellulose die wordt afgebroken is evenredig met de hoeveelheid biogas die deze microorganismen produceren. Er bleek een keurige positieve relatie te bestaan tussen de verlaging van de hoeveelheid tignin de champost en de hoeveelheid geproduceerd biogas.Echter de maximale hoeveelheid biogas die kon worden geproduceerd op basis van schimmel behandelde champost bleef ver achter bij de hoeveelheid biogas die kan worden geproduceerd op basis van tarwestro. Daardoor is het gebruik van champost als feedstock voor biobased toepassingen niet rendabel.

In een tweede deel van het project is gekeken naar de mogelijkheid om polysacchærbøkende enzymen te extraheren uit champost. Het enzymextract dat uit ampost kon worden gewonnen bleek nauwelijks cellulase activiteit te bevatten. Er was wel een aanzienlijke hemicellulase activiteit. Echter, aangezien polysaccharide afbrekende enzymen tegenwoordig tegen lage kostprijs kunnen worden geproduceerd is het rzeer de vraag of winning van hemicellulases uit champost daar mee kan concurreren. Er is wel een markt voor hemicellulases met speciale specificiteiten, maar het is onwaarschijnlijk dat champignon dergelijke hemicellulases maakt.

Tot slot is geprobeerd ofchampost zou kunnen dienen als substraatcomponent in de teelt van koningsoesterzwam.Teeltresultaten lieten zien dat vervanging van $27 \%$ van het zaagsel in het substraatmengsel geen negatief of positief effect heeft op de opbrengst aan paddenstoelen. Imdidle zaagsel in het substraatmengsel wordt vervangen door champost, daalt de opbrengst aan oesterzwammen met $35 \%$. Voor alle substraatmengsels met champost bleek echter dat de kolonisatie door koningsoesterzwam mycelium ongeveer anderhalf keer zo lang dưt. Deze relatief trage ingroei van het mycelium maakt het onwaarschijnlijk dat in de praktijk champost in het substraat voor koningsoesterzwam zal worden verwerkt. 


\section{Inleiding}

Het onderzoek naar de vraag of Champost waarde heeft als biobased product is onderdeel van een groter project met de titel "Increasing utilization of organic waste and low value feeds with the help of lignin degrading fungi".

Het doel van dit door STW gefinancierde project (STW nr 11611) is om schimmels te gebruiken om lage kwaliteit voer en organisch afval op te waarderen, zodat het na behandeling een hogere voedings waarde heeft voor herkauwers en gebruikt kan worden bio-fermentatoren voor de productie van vluchtige vetzuren en methaan en voor de productie van ethanol. De belangrijkste beperkende factor in deze lage kwaliteit diervoeders en afvalstoffen is de aanwezigheid van een hoog gehalte aan lignine. Hierdoor kunnen de waardevolle koolhydraten in plantaardige celwanden niet benut worden. Lignine kan niet worden afgebroken middels anaerobe vergisting, zoals dat in de pens van herkauwers plaats vindt. Alleen schimmels zijn in staat om de complexe structuren van lignine af te breken. Schimmels die worden gebruikt om paddenstoelen te produceren op lignocellulose complexen zijn aangepast aan deze complexe substraten. Deze schimmels hebben een strategie om het substraat eerst te koloniseren en modificeren daarbij het substraat op een zodanige wijze dat de (hemi) cellulose heel snel beschikbaar kan komen als de paddenstoelen worden geproduceerd. Gedurende de vegetatieve groei produceren deze schimmels bij voorkeur enzymen die gericht zijn op het afbreken en/ of modificeren van lignine, om voor de vorming van de paddenstoelen heel snel te kunnen overschakelen op de afbraak van cellulose en hemicellulose. Door het proces te stoppen voordat vruchtlichamen gevormd worden, zal dat resulteren in een substraat met minder lignine en minder beperkingen voor de afbraak van de celwandkoolhydraten. Dus, sommige soorten witrot-schimmels zijn in staat om specifiek lignine af te breken en/of te modificeren tijdens de vegetatieve groei, zonder dat de andere koolhydraten in plantaardige celwanden worden afgebroken. Met behulp van deze schimmels wordt de afbreekbaarheid van de substraten (plantencelwanden) verbeterd, hetgeen resulteert in een hogere voederwaarde en verhoogde synthese van vluchtige vetzuren, en wanneer deze substraten worden toegepast in bio-fermentatoren, een verhoogde synthese van methaan en vluchtige vetzuren.

De delignificeerde substraten kunnen niet alleen worden gebruikt als voer voor herkauwers, maar ook als substraat voor de productie van methaan (co-vergisting), chemische componenten (vluchtige vetzuren, suikers) en (bio) ethanol. Daarnaast biedt co-vergisting van het voorbehandelde organische materiaal met afvalwater slib een manier om waterzuiverings installaties netto energieproducenten te maken.

In dit project wordt onderzoek gedaan naar de meest geschikte schimmels en de meest optimale condities voor maximale afbraak cq. modificatie van lignine, voor een maximale beschikbaarheid van de koolhydraten in het behandelde substraat voor verschillende toepassingen. De waarde van het gedelignificeerde materiaal zal onderzocht worden voor herkauwervoeding, co-vergisting voor methaan en vluchtige-vetzuurproductie en de productie van ethanol.

Champost bestaat uit een mengsel van compost en dekaarde dat na de teelt uit de teeltruimten wordt gehaald. Vaak, maar zeker niet altijd is de champost gedurende 8 uur verhit bij $70^{\circ} \mathrm{C}$ voordat de teeltruimten worden geopend. Straatsma (2006) schat de jaarlijkse productie van champost op ongeveer 910000 ton. Momenteel wordt champost vooral afgezet als meststof/bodemverbeteraar. De hoeveelheid champost die op het land mag worden gebracht wordt beperkt door wettelijke regelingen. De hoeveelheden stikstof en fosfaat in de champost vormen de voornaamste beperkende factoren in het landbouwkundig gebruik van champost. In 2002 is een studie uitgevoerd door Zhu en Van Roestel (2002) naar de mogelijkheden voor hergebruik van champost. Zij concludeerden toendertijd dat gebruik als meststof/bodemverbeteraar het meest perspectiefvol was, maar dat er rekening moest worden gehouden met een lage (of negatieve) verkoopprijs. Een andere beperkende factor in de afzet is het relatief hoge zoutgehalte van champost. Indien een gedeelte van de zouten uit de champost geloogd kunnen worden, is champost beter bruikbaar (Gonani et al., 2011, http:// www.wageningenur.nl/nl/ project/Valoris atie-Champost.htm). Vanwege de beperkingen die de minerale samenstelling van champost oplegt aan de hoeveelheid die per hectare landbouwgrond mag worden verwerkt, is het meeste analyse-werk verricht aan de minerale samenstelling. Straatsma (2006) geeft het volgende overzicht van de samenstelling van champost: 
Tabel 1. Tabel. Samenstelling van 25 Nederlandse Champost monsters per jaar uit de jaren 2001, 2002 en 2005 (Straatsma 2006).

\begin{tabular}{|c|c|c|c|c|c|c|c|}
\hline Parameter & Eenheid & Gemiddelde & $\begin{array}{l}\text { Standaard } \\
\text { deviatie }\end{array}$ & Minimum & Maximum & $\begin{array}{l}\text { Aantal } \\
\text { monsters }\end{array}$ & $\begin{array}{l}\text { Aantal } \\
\text { monsters } \\
\text { onder de } \\
\text { detectielimiet }\end{array}$ \\
\hline Droge stof & $\mathrm{g} / \mathrm{kg}$ & 327 & 33 & 245 & 416 & 75 & \\
\hline $\begin{array}{l}\text { Organische } \\
\text { stof }\end{array}$ & $\begin{array}{l}\% \text { van } \\
\text { droge } \\
\text { stof }\end{array}$ & 61 & 2.5 & 54.2 & 65.8 & 75 & \\
\hline $\begin{array}{l}\text { Stikstof in } \\
\text { droge stof }\end{array}$ & $\mathrm{g} / \mathrm{kg}$ & 20.8 & 1.6 & 15.9 & 24.9 & 74 & \\
\hline $\begin{array}{l}\text { Fosfor } \\
\left(\mathrm{P}_{2} \mathrm{O}_{5}\right)\end{array}$ & $\mathrm{g} / \mathrm{kg}$ & 12.1 & 1.7 & 7.8 & 17.0 & 75 & \\
\hline $\mathrm{K}_{2} \mathrm{O}$ & $\mathrm{g} / \mathrm{kg}$ & 23.4 & 4.9 & 15.5 & 36.0 & 74 & \\
\hline $\mathrm{Cd}$ & $\mathrm{mg} / \mathrm{kg}$ & 0.27 & 0.05 & 0.20 & 0.41 & 66 & 9 \\
\hline $\mathrm{Cr}$ & $\mathrm{mg} / \mathrm{kg}$ & 7.5 & 3.7 & 3.5 & 26.0 & 74 & 1 \\
\hline $\mathrm{Cu}$ & $\mathrm{mg} / \mathrm{kg}$ & 34.1 & 16.3 & 17.0 & 112.0 & 75 & \\
\hline $\mathrm{Hg}$ & $\mathrm{mg} / \mathrm{kg}$ & 0.04 & 0.01 & 0.03 & 0.07 & 67 & 8 \\
\hline $\mathrm{Ni}$ & $\mathrm{mg} / \mathrm{kg}$ & 4.4 & 1.3 & 2.7 & 12.0 & 74 & 1 \\
\hline $\mathrm{Pb}$ & $\mathrm{mg} / \mathrm{kg}$ & 7.2 & 2.0 & 6.3 & 16.0 & 30 & 45 \\
\hline $\mathrm{Zn}$ & $\mathrm{mg} / \mathrm{kg}$ & 135 & 24 & 56 & 192 & 75 & \\
\hline As & $\mathrm{mg} / \mathrm{kg}$ & 1.8 & 0.9 & 1.1 & 4.3 & 70 & 5 \\
\hline EC & $\mathrm{mS} / \mathrm{cm}$ & 13.0 & 1.9 & 9.9 & 18.8 & 74 & \\
\hline $\mathrm{C} / \mathrm{N}$ & schatting & 10.4 & 1.2 & 8.2 & 14.1 & 74 & \\
\hline
\end{tabular}

De waarden in bovenstaande tabel komen grotendeels overeen met waarden die in 1994 werden gepubliceerd door Gerrits (1994) over de samenstelling van champost over een falrige periode van 1966 tot 1993 en met de waarden die Gerrits in 1997 publiceerde ovele aanwezigheid van meer dan 30 verschillende mineralen in champost zoals gemeten in een ringte\$(Gerrits, 1997) De verschillen tussen verschillende batches champost lijken in Nederland relatief klein. In andere landen, waar compost productie veel reirid gecentraliseerd dan in Nederland, kunnen de verschillen groter zil[_zmidt \& Chong, 1995.)Bij interpretatie van de literatuur over de samenstelling van champost (SMS; spent mushroom substrate) dient rekening gehouden te worden met mogelijke afwijkingen van de Nederlandse champost.

Andere toepassingen die Zhu \& Van Roes(2002) perspectiefvol toeschenen warerproductie van biogas door vergisting, hergebruik van champost als substraat bij andere paddenstoelen en, als laatste, extractie van waardevdle componenten uit champost. Zij geven echter geen voorbeeld van mogelijk waardevolle componenten in champost.

Eventueel waardevolle componenten in champost zouden aanwezig kunnen zijn in de organische stof fractie in champost. Gerrits et al.(1967) bestudeerden de samenstelling van compost op verschillende tijdstippen tijdens compostbereiding en teelt van champignons. Zij kwamen tot de conclusie dat tijdens de compostering en pasteurisatie de totale hoeveelheid lignine gelijk blijft, terwijl de hoeve@lhillulose en hemicellulose snel afneemt. $\mathrm{Na}$ enten met champignonmycelium neemt de hoeveelheid lignine snel af, terwijl cellulose en hemicellulose een beetje afnemen. Tijdens het composteren wordt oplosbaar stikstof omgezet in onoplosbaar stikstof (inbiouw thermofiele microflora en incorporatie in een stikstøijk ligninehumuscomplex). Tijdens de teelt consumeert de champignon de micreorganismen en het complex. Aan het eind van de teelt vonden zij op basis van 4 experimenten globaal de volgende samertelling van de resterende compost; asgehalte tussen 28.6 en 44.2\% DM, wateroplosbare componenten tussen 30.5 en $34.4 \%$ DM, lignine gehalte tussen 16.5 en $20.4 \%$ DM, hemicellulose gehalte tussen 3 en $11.6 \%$ DM en cellulose gehalte tussen 6.1 en 18\% DM. Voobelæiding van de vier composten werden 2 verschillende recepturen gebruikt, hetgeen mede een verklaring voor de grote variatie in de waarden geeft. 
In een latere studie richtte Gerrits (1969) zich op de organische bestanddelen van de compost tijdens de compostkolonisatie en de fructificatie. Hij kwam tot de conclusie dat het grootste deel van de lignine (63-92\% van de geconsumeerde lignine) tijdens de compostkolonisatie werd afgebroken. De cellulose en hemicellulose werden tijdens de compostkolonisatie slechts weinig afgebroken, en vooral tijdens de vruchtlichaamvorming. Aan het eind van de teelt vond hij op basis van 4 experimenten globaal de volgende samenstelling van de resterende compost; asgehalte tussen 31.6 en $55.8 \% \mathrm{DM}$, wateroplosbare componenten tussen 30.2 en $32.5 \% \mathrm{DM}$ lignine gehalte tussen 13.7 en $24.6 \%$ DM, hemic ellulose gehalte tussen 1.9 en $7.3 \%$ DMen cellulose gehalte tussen 5.2 en $12.1 \%$ DM Voor de bereiding van de vier composten werden 2 verschillende recepturen gebruikt, hetgeen mede een verklaring voor de grote variatie in de waarden geeft.

liyama et al (1994) beschreven experimenten waarin de samenstelling van een Australische champignoncompost werd bepaald op verschillende momenten tijdens de compostbereiding en de teelt van champignons. Na 4 vluchten werd daarin ook de champost geanalyseerd. In deze champost werd een lignine gehalte van $23.5 \% \mathrm{DM}(32.5 \% \mathrm{OM})$ gevonden. Nadat gemakkelijk oplosbare stoffen uit de champost waren geëxtraheerd, werd het residu met zuur gehydrolyseerd om de samenstellende suikers te bepalen. In de vezelfractie van de champost werd voornamelijk glucose $(10.1 \%$ van het organisch materiaal), xylose (3.6\%), arabinose $(0.8 \%)$, mannose en galactose (ieder $0.4 \%$ ) gevonden.

Chen et al. (2000) bestudeerden bij Penn State University (VS) een compost gebaseerd op 6-8 ton paardemest, $135 \mathrm{~kg}$ kippemest, $135 \mathrm{~kg}$ gips en $135 \mathrm{~kg}$ bierbostel. Zij analyseerden tijdens de teelt gedurende 4 vluchten na elke vlucht de samenstelling van de compost. Na de derde vlucht bevatte de compost nog $55 \%$ organische stof en na de vierde vlucht was dat gedaald tot $53.3 \%$ Compost monsters werden met $2 \mathrm{~N}$ zwavelzuur gehydrolyseerd om de suikersamenstelling te analyseren. Na hydrolyse vonden ze na de derde vlucht ongeveer 25 $\mu \mathrm{g}$ aan suikers per mg droge stof. In de compost werden glucose $(8-9 \mu \mathrm{g} / \mathrm{g} \mathrm{DM})$, fucose en arabinose (samen ong

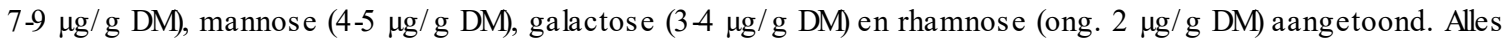
tezamen vertegenwoordigden deze suikers ongeveer 4-5\% van de totale organische stof.

In een door het Productschap Tuinbouw gefinancierd project is in 2010-2011, gebruikmakend van CNC compost een teelt uitgevoerd waarin 2 vluchten champignons werden geoogst. De champost die na deze twee vluchten resteerde, werd m.b.v. NIR-spectroscopie een schatting gemaakt van de samenstelling (Tabel2).

Tabel 2. Samenstelling van champost uit 2010 na productie van 2 vluchten champignons op CNC compost (op basis van NIR-spectrometrie).

\begin{tabular}{|l|l|}
\hline Parameter & $\mathbf{K g} / \mathrm{ton}$ \\
\hline Droge stof & 359,5 \\
\hline As & 137.8 \\
\hline Organische stof & 221.7 \\
\hline Lignine & 55.9 \\
\hline Cellulose & 53.8 \\
\hline Hemicellulose & 3.7 \\
\hline Wateroplosbaar & 108.3 \\
\hline
\end{tabular}

Het in de champost resterende cellulose en hemicellulose wordt door lignine afgeschermd tegen afb(耳ak Have et al., 2003). Bij hergebruik van champost als substraat voor andere eetbare paddenstoelen, zal de paddenstoelsoort in staat moeten zijn om de cellulose en hemicellulose in de champost af te brekerrolvit basidiomyceten zouden daar mogelijk tơn staat zijn. Er zijn echter geen publicaties bekend waarin een succesvolle teelt met champost als (dee)substraat is beschreven.

In het in dit rapport beschreven project wordt onderzocht of witrøchimmels in staat zijn om de resterende holocellulosein champost verder beschikbaar te maken voor gebruik in de łhiesed economy. 


\section{Testen van schimmelgroei op champost}

\subsection{Gebruikte champost}

Champost werd aangeleverd door Emons Recycling Logistics in Mils beek (Figuur 1). Bij aankomst in het lab werd de champost gedroogd bij $70^{\circ} \mathrm{C}$, vermalen tot fragmenten van ongeveer $24 \mathrm{~mm}$ en droog bewaard tot gebruik.

\subsection{Gebruikte schimmelstammen}

Een overzicht van de schimmelsoorten die geselecteerd werden voor groei op champost wordt gegeven in Tabel 3. De schimmels werden voor de experimenten uit de collectie in vloeibare stikstof gehaald en ontdooid. Vervolgens werden de schimmelkolonies in stand gehouden op mout-extract/mycologisch pepton tot gebruik. Niet alle geselecteerde schimmels zijn hout-afbrekende witrots chimmels. Lepista nuda (de Paarse Schijnridderzwam) is bijvoorbeeld een saprofytis che schimmel.

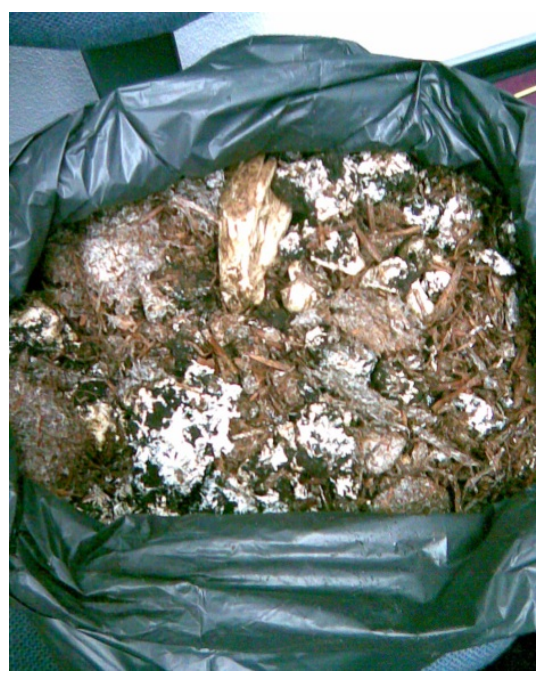

Figuur 1. De champost zoals aangeleverd voor gebruik in het project.

Tabel 3. Overzicht van de 11 schimmelsoorten die geselecteerd werden voor het testen van groei op champost.

\begin{tabular}{|l|l|l|l|}
\hline Nr. & Collectie-nummer & Soort & Opmerkingen \\
\hline 1 & MES 11937 & Clitocybula dusenii & DSM-11238 \\
\hline 2 & MES 11922 & Trametes suaveolens & $=$ CCBAS611 \\
\hline 3 & MES 03464 & Pleurotus sajołcaju & $=$ Amycel 3011, commercieel verkrijgbare stam \\
\hline 4 & MES 02055 & Trametes versicolor & $=$ Wild isolæat, onbekende oorsprong \\
\hline 5 & MES 11908 & Gymnopilus sapineus & $=$ CCBAS372 \\
\hline 6 & MES 11919 & Bjerkandera adusta & $=$ CCBAS930 \\
\hline 7 & MES 11856 & Stropharia rugoseannulata & $=$ SR11, isolaat uitDuitsland (Dr. Egbert Seibertz) \\
\hline 8 & MES 11910 & Lentinula edodes & $=$ CCBAS389 \\
\hline 9 & MES 03412 & Pleurotus eryngii & $=$ Somycel 3060, commercële stamn \\
\hline 10 & MES 13094 & Ceriporiopsis subvermispora & $=$ CBS 347.63, isolaat uit de VS \\
\hline 11 & MES 03218 & Lepista nuda & $=$ Wild isolæat, gevondenin "de Rosmolen" Geysteren \\
\hline
\end{tabular}

\subsection{Geteste substraten}

\subsubsection{Groei op champost}

Alle schimmels in Tabel 3 werden getest op hun vermogen om te groeien op champoi op champost werd gemeten als lineaire groeisnelheid in een glazen bués $21 \mathrm{~mm}$ ). Hiervoo werd de champost gerehydrateercen vervolgens werd in elke buis eenzelfde gewicht aan champost afgevuld tot dezelfde vulhoogte. Hierdoor werd in elke buis dezelfde bulkdensity van het substraat bereikt. Na sterilisatie (2 maal 1 uur op 1\%lom hiteresistente sporen af te doden) werd het substraat bent met 5 entpuntjes. Entpuntjes werden genomen uit een groeiende kolonie met een steriele krukboor van $5 \mathrm{~mm}$ doorsnede. De buizen werden vervolgens bflegeincubeerd in een warme kamer bij een RV van 70\%Groei van het mycelium werelke 2 tot 3 dagenvastgelegd op 4 assen langs de lengterichting van de buisvoor een periode tot maximaal 62 dagerDe myceliumgroei werd gevolgd over de volledige lengte van de champostkolom $(12 \mathrm{~cm})$. Voor elkechimmel werd groei op 3 buizen gevolgd. 
Nadat de buizen volledig doorgroeid waren werd de kolonisatie op verschillende tijdstippen afgebroken; meteen bij het bereiken van de bodem van de buis, 2 weken na het bereiken van de bodem van de buis en 4 weken na het bereiken van de bodem van de buis. De op deze manier met nieuwe schimmel gekoloniseerde champost werd gedroogd bij $70^{\circ} \mathrm{C}$ en bewaard voor verdere analyse.

Van de 11 geteste schimmels bleken alleek/eurotus eryngii Pleurotus sajotcaju, Trametes suaveolenstrametes versicolor, Clitocybula duseniiGymnopilus sapineuen Bjerkandera adustän staat te zijn om champoste koloniseren.Stropharia rugoseannulata Lentinula edodes Ceriporiopsis subvermisporen Lepista nudavertoonden slechte groei Figuur 2 toont als voorbeeld de lineaire groei van Trametes versicolorp gesteriliseerde champost. Na een lagfase van een antal dagen vertoont de schimmel een mooie lineaire groeisnelheid. Deze houdt aan totdat na 25 dagen de champost over een afstand van $100 \mathrm{~mm}$ is gekoloniseerd. Vervolgens neemt de groeisnelheid af, hetgeen waarschijnlijk te wijten is aan het feit dat de champostlaag in de buis slechts $120 \mathrm{~mm}$ diep wasn het lineaire stuk van de grafiek kan de maximale groeisnelheid van het mycelium worden berekend.

Tabel 4. Lineaire groeisnelheden van de geteste schimmelstammen op champost.

\begin{tabular}{|l|l|c|}
\hline Schimmelsoort & Stam & 7.1 \\
\hline Trametes suaveolens & MES 11922 & 5.3 \\
\hline Pleurotus sajotcaju & MES 03464 & 4.3 \\
\hline Trametes versicolor & MES 02055 & 4.2 \\
\hline Pleurotus eryngii & MES 03412 & 3.9 \\
\hline Bjerkandera adusta & MES 11919 & 3.0 \\
\hline Clitocybula dusenii & MES 11937 & 2.0 \\
\hline Gymnopilus sapineus & MES 11908 & 0 \\
\hline Stropharia rugoseannulata & MES 11856 & 0 \\
\hline Lentinula edodes & MES 11910 & 0 \\
\hline Ceriporiopsis subvermispora & MES 13094 & 0 \\
\hline Lepista nuda & MES 03218 & (mm/dag) \\
\hline
\end{tabular}

\subsubsection{Groei op mengsels van champost}

De schimmelsC. subvermisporæn L. edodesbleken niet in staat om op champost te groeien. Deze beide schimmels bleken echter in de overige experimenten binnen \$etW gefinancierde projeøp andere lignocellulose houdende substraten zeer interessant. Ondie reden is hun groei nogmaals getest, echter in dit geval op mengsels van champost met andere lignocellulose bronnen. Figuur 3 laat zien dat bij groei op Miscanthus en tarwestro het toevoegen van $5 \%(\mathrm{w} / \mathrm{w})$ champostan het substraatreeds een verminderingan de lineaire groeisnelheid tot gevolg heeft. Daar staat tegenover dat bij groei op snoeihout zelfs het toevoegen van $20 \%$ champost geen remming op de linaire groeisnelheid geeft. Bił entinula edodesieeft toevoegen van $5 \%$ champost aan een substraat van Miscanthus weinig effect op de groeisnelheid. Toevoeging van grotere hoeveelheden champost geeft een lichte remming van de lineaire groeisnelheid. Bij groei vłn edodesop tarwestro wordt een vergelijkbaar beeld gezien, zij het dan dat toevoeging van $2 \%$ champost aan het substraat een iets sterkere remming van de groeisnelheid tot 

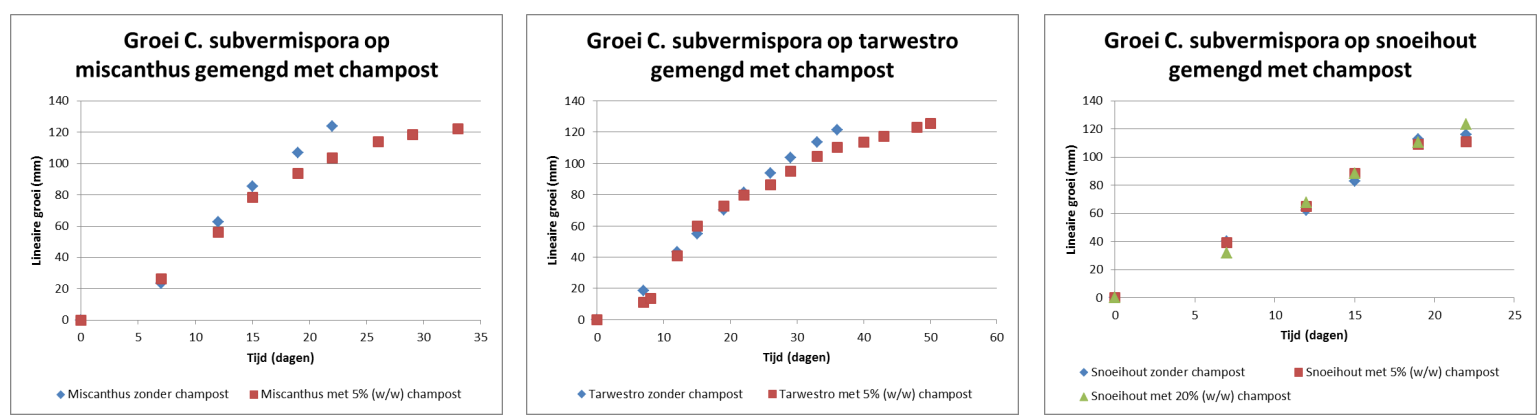

Figuur 4. Groei van Ceriporiopsis subvermispora op verschillende lignocellulose houdende substraten, gemengd met champost.
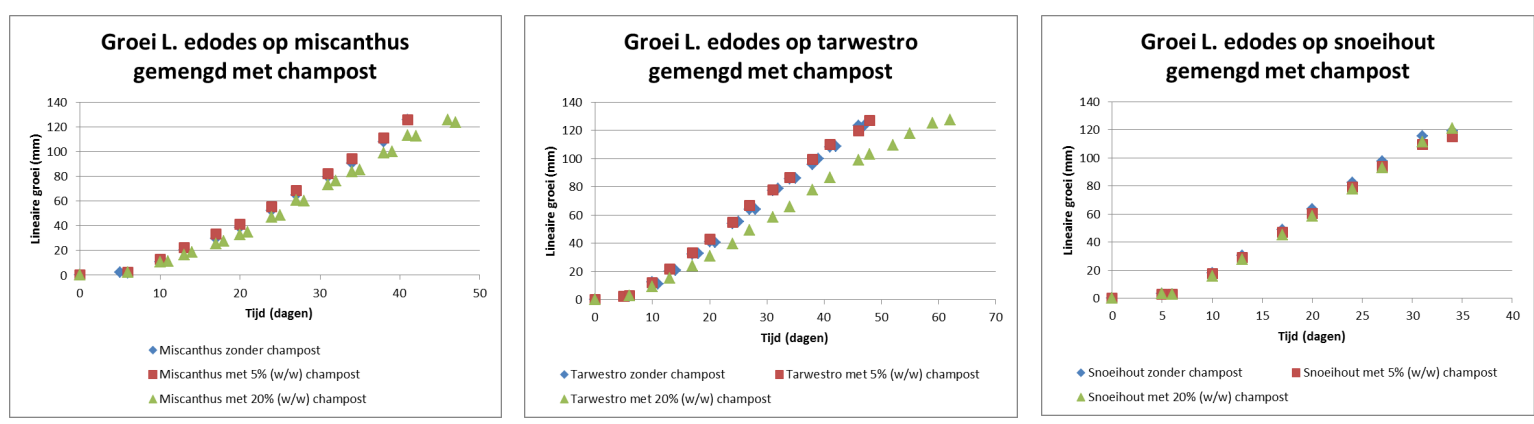

Figuur 4. Groei van Lentinula edodes op verschillende lignocellulose-houdende substraten gemengd met champost.

gevolg heeft. Bij groei vanL. edodesop snoeihout heeft zelfs het toevoegen van $20 \%$ champost geen effect op de groeisnelheid van de schimmel.

\section{$3.4 \quad$ Discussie}

Samenvattend kan gezegd worden dat typische witrot-schimmels zoals Pleurotus eryngjiPleurotus sajorcaju Trametes suaveolenstrametes versicolor Clitocybula duseniiGymnopilus sapineusn Bjerkandera adustàn staat zijn om uit (gesteriliseerde) champost nog voldoende voeding te halen om te kunnen groeien. De witrotters Lentinula edodesen Ceriporiopsis subvermisporan de schimmels Stropharia rugoseannulatan Lepista nudableken niet in staat te groeien op champost. De gebruikte stammen van $L$. edodesen $C$. subvermisporableken prima in staat om te groeien op miscanthus, tarwestro en houtsnippers. Toevoeging van champost had een remmend effect op de lineaire groeisnelheid en dat suggereert ofwel een tekort aan voedingstoffen of de aanwezigheid van een remmende factor in de champost.

Ter nuancering van de relatief hoge lineaire groeisnelheden van de witrotschimmels bij groei op uitsluitend champost, moet worden opgemerkt dat een lineaire groeisnelheid niet gelijkstaat aan een goede vorming van biomassa. Ter illustratie, in October 1999 is een teeltproef (proefnummer 22815) uitgevoerd waarin oesterzwam (Pleurotus ostreatus ras HK35) werd geteeld op mengsels van stro en champost. Hierbij werd gewerkt met mengsels van:

- $0 \%$ champost / $100 \%$ nat stro

- $25 \%$ champost $/ 75 \%$ nat stro

- $50 \%$ champost / $50 \%$ nat stro

Bij aanlevering van de grondstoffen werd bemonsterd en werd geanalyseerd op vochtgehalte, $\mathrm{pH}$, ammonium-N, totaal $\mathrm{N}$ en asgehalte. Het stro had een asgehalte van $10 \%$ terwijl de champost een asgehalte van bijna $40 \%$ had. $\mathrm{Na}$ grondig mengen van de grondstofmengsels werd gepasteuriseerd bij $70^{\circ} \mathrm{C}$ gedurende 10 uur. Vervolgens werd gedurende 4 dagen geconditioneerd bij $45^{\circ} \mathrm{C}$. Het substraat werd geent met ras HK-35 (25 liter/ton substraat) en in pakketten geperst. Vervolgens werden de pakketten gedurende geïncubeerd in teeltcellen. In de controle $(0 \%$ champost $/ 100 \%$ stro) liep de temperatuur van het substraat op tot een temperatuur van $32^{\circ} \mathrm{C}$. Om oververhitting te voorkomen werd de luchttemperatuur in de teeltcel verlaagd van $24^{\circ} \mathrm{C}$ naar $20^{\circ} \mathrm{C}$. Na 6 dagen zag het substraat 
met $0 \%$ champost er goed doorgroeid uit. In het substraat met $25 \%$ champost groeit het mycelium moeizaam. In substraat met $50 \%$ champost groeit het mycelium niet echt van de entpuntjes (=broedkorrels) af. Aan het einde van de substraatkolonisatie (na 17 dagen) zagen alle substraten er echter goed doorgroeid uit. Na een substraatkolonisatie van 17 dagen werd afgeventileerd. De luchttemperatuur werd daarbij in enkele dagen verlaagd naar $16^{\circ} \mathrm{C}$, een $\mathrm{RV}$ van $96 \%$ en een $\mathrm{CO}_{2}$ gehalte van $680 \mathrm{ppm}$. Bij het substraat met $0 \%$ champost waren op dat moment de eerste knopjes met jonge paddenstoelen al zichtbaar. Al na 6 dagen na afventileren begint de oogst. De opbrengsten (Tabel 5) werden bepaald inclusief de voetjes (het afval).

Tabel 5. Productie aan oesterzwammen op tarwestro-substraat, gemengd met verschillende hoeveelheden champost.

\begin{tabular}{|l|c|c|c|}
\hline Substraatmengsel & \# pakketten & $\begin{array}{c}\text { Gemiddelde opbrengst aan oesterzwammen } \\
\text { per pakket (kg) }\end{array}$ & Standaard deviatie \\
\hline $0 \%$ champost & 21 & 23.9 & 2.9 \\
\hline $25 \%$ champost & 21 & 23.5 & 2.4 \\
\hline $50 \%$ champost & 21 & 13.1 & 2.1 \\
\hline
\end{tabular}

Variantieanalyse gaf aan dat op het mengsel met $25 \%$ champost evenveel is geproduceerd als in de controle met $0 \%$ champost. Opbrengst oæen mengsel met $50 \%$ champost ligt $45 \%$ lageDe oesterzwammen van substraatmengsel met $0 \%$ champost hadden een normale kwaliteit. Bij de substraatmengsels die wel champost bevatten, waren er duidelijke kwaliteitsproblemen; slechte uitgroei van de paddensovererkleuring of afsterven van trossen met paddenstoelenNa het oogsten van 3 vluchten paddenstoelen werd het substraat weef ge analyseerd. $\mathrm{Bij} 0$ en $25 \%$ champost in het tarwestroubstraat was de $\mathrm{pH}$ (o.a. een maat voor de doorgroeiing met mycelium) geciald tot 4.9. Bij 50\% champost was de $\mathrm{pH}$ gedaald tot 5.2. Daarnaast bleek in het tarwestabstraat de hoeveelheid droge stof met $22 \%$ te zijn gedaald. In het substraat met $25 \%$ en $50 \%$ champost was respectievelijk 16 en $12 \%$ van de droge stof verdwenerWe mogen aannemen dat de verdwenen droge stof in principe nagenoeg vollediguit organische stof bestaat.

Het toevoegen van champost aan substraat voor oesterzwarf/\&urotus ostreatuseen bijzonder nauwe verwant vanPleurotus sajoxaju) had dus tot gevolg dain een pakket met substraat minder voedsel aanwezig was voor het maken van paddenstoelen (verminderde opbrengst en kwaliteit). 


\section{Toegankelijkheid cellulose en hemicellulose na behandeling van champost met schimmels}

\subsection{Effect doorgroeiing van champost met witro $t$ schimmels op het lignine -gehalte.}

Zoals beschreven in $\S 2.3 .1$. bleek het mogelijk om steriele champost in volgorde van afnemende groeisnelheid te laten doorgroeien doorTrametes suaveolensPleurotus sajoxaju, Trametes versicolor Pleurotuseryngii Bjerkandera adustaClitocybula dusenën Gymnopilus sapineußMet uitzondering vanG. sapineuswerden de doorgroeide champost monsters geanalyseerd op acid detergent Lignin (ADL) gehal Łel 6 geeft een overzicht van de ligninegehalten na vdedige doorgroeiing van de champost met witrestchimmels. Daarnaast is in de Tabel ook de lineaire groeisnelheid van de verschillende schimmelsoorten aangegevłaurotus eryngièn Pleurotus sajor-caju bleken het beste in staat om het ligninegehalte ide champost te verlagenDe beide Trametessoorten bleken slechts beperkt in staat om het ligninegehalte te verlagen. Een hoge lineaire groeisnelheid in champost blijkt dit geen indicator te zijn van verregaande afbraak van lignine.

Tabel 6. Effect van het doorgroeien van champost met witrot-schimmels op het ligninegehalte (gemeten als Acid Detergent Lignin, ADL)

\begin{tabular}{|c|c|c|c|c|}
\hline Schimmelsoort & $\begin{array}{l}\text { Lineaire } \\
\text { groeisnelheid } \\
\text { (mm/dag) }\end{array}$ & $\begin{array}{l}\text { Lignine -gehalte ( } \% \\
\text { ADL) }\end{array}$ & $\begin{array}{l}\text { standaard } \\
\text { deviatie }\end{array}$ & $\mathbf{n}$ \\
\hline $\begin{array}{l}\text { Niet met witrot-s chimmel doorgroeide } \\
\text { champost }\end{array}$ & n.v.t. & 31.6 & & 1 \\
\hline Trametes suaveolens & 7.1 & 30.8 & 3.0 & 3 \\
\hline Trametes versicolor & 4.3 & 27.9 & 2.3 & 3 \\
\hline Bjerkanderaadusta & 3.9 & 27.9 & 0.9 & 3 \\
\hline Clitocybe dusenii & 3 & 24.6 & 1.6 & 3 \\
\hline Pleurotus sajor-caju & 5.3 & 24.0 & 0.9 & 3 \\
\hline Pleurotuseryngii & 4.2 & 21.0 & 1.7 & 3 \\
\hline
\end{tabular}

\section{2 \\ Vermogen van witrot -schimmels om cellulose in champost beschikbaar te maken voor enzymatische afbraak.}

Om te achterhalen in hoeverre de behandeling met witrot-schimmels het resterende cellulose en hemicellulose in champost beschikbaar maakt voor enzymatische afbraak, werd gebruik gemaakt van een modelsysteem voor het vaststellen van de verteerbaarheid van lignocellulose in de pens. De micro-organismen in de pens zijn specialisten in het afbreken van cellulose in de celwanden van planten. Ze zijn echter niet in staat om lignine af te breken in de zuurstofloze atmosfeer in de pens. Als er meer koolhydraten beschikbaar zijn, zullen de pens-micro-organismen meer substraat afbreken met als gevolg een verhoogde productie van vluchtige vetzuren en $\mathrm{CO}_{2}$ en methaan (biogas). De toegankelijkheid van cellulose voor de enzymen van de pens-microorganismen laat zich daardoor aflezen aan de hand van de hoeveelheid biogas die geproduceerd wordt (Cone et al., 1996).

Tabel 7 toont de gemiddelde biogasproductie als champost doorgroeid met witrotschimmels wordt aangeboden aan pensmicroorganismen. Hoe hoger de biogasproductie, hoe beter het cellulose in het monster 
toegankelijk is voor de cellulose-afbrekende enzymen in de pens. Zonder schimmelbehandeling zijn de pensmicroorganismen slechts tot een erg lage gasproductie in staat (21.1 ml per gram organische stof). Ter vergelijking; op basis van tarwestro en snoeihout zijn de pens-microorganis men in staat om respectievelijk ongeveer $200 \mathrm{ml}$ en ongeveer $85 \mathrm{ml}$ gas te produceren per gram organische stof. Doorgroei van de champost met

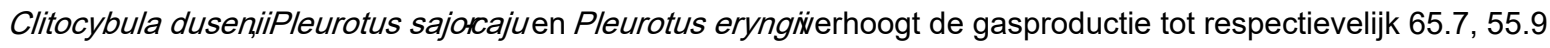
en $51.7 \mathrm{ml} / \mathrm{gram}$ organische \$of. Dat is echter nog altijd aanzienlijk minder dan de gasproductie door onbehandeld snoeihout.

Tabel 7. Biogasproductie door pens-microorganismen gevoed met champost doorgroeid met witrotschimmels als maat voor de toegankelijkheid van de cellulose in de champost.

\begin{tabular}{|l|c|c|c|}
\hline Schimmel & Gasproductie (in mlgram organische stof ) & Std. Dev & $\mathbf{n}$ \\
\hline Clitocybuladusenii & 65.7 & 17.7 & 3 \\
\hline Pleurotus sajorcaju & 55.9 & 4.1 & 3 \\
\hline Pleurotus eryngii & 51.7 & 6.1 & 3 \\
\hline Trametes suaveolens & 39.7 & 4.9 & 3 \\
\hline Trametes versicolor & 39.2 & 6.8 & 3 \\
\hline Bjerkanderaadusta & 25.8 & 0.0 & 1 \\
\hline Onbehandelde champost & 21.1 & 0.7 \\
\hline
\end{tabular}

Er lijkt overigens een relatie te bestaan tussen het lignine gehalte van de champost (uitgedrukt als \% ADL) en de in vitro gas productie. Hoe lager het ligninegehalte, hoe hoger gesproductie Dit lijkt de hypothese te ondersteunen dat het cellulose wordt afgeschermd tegen enzymatische afbradkor het lignine in het substraat.

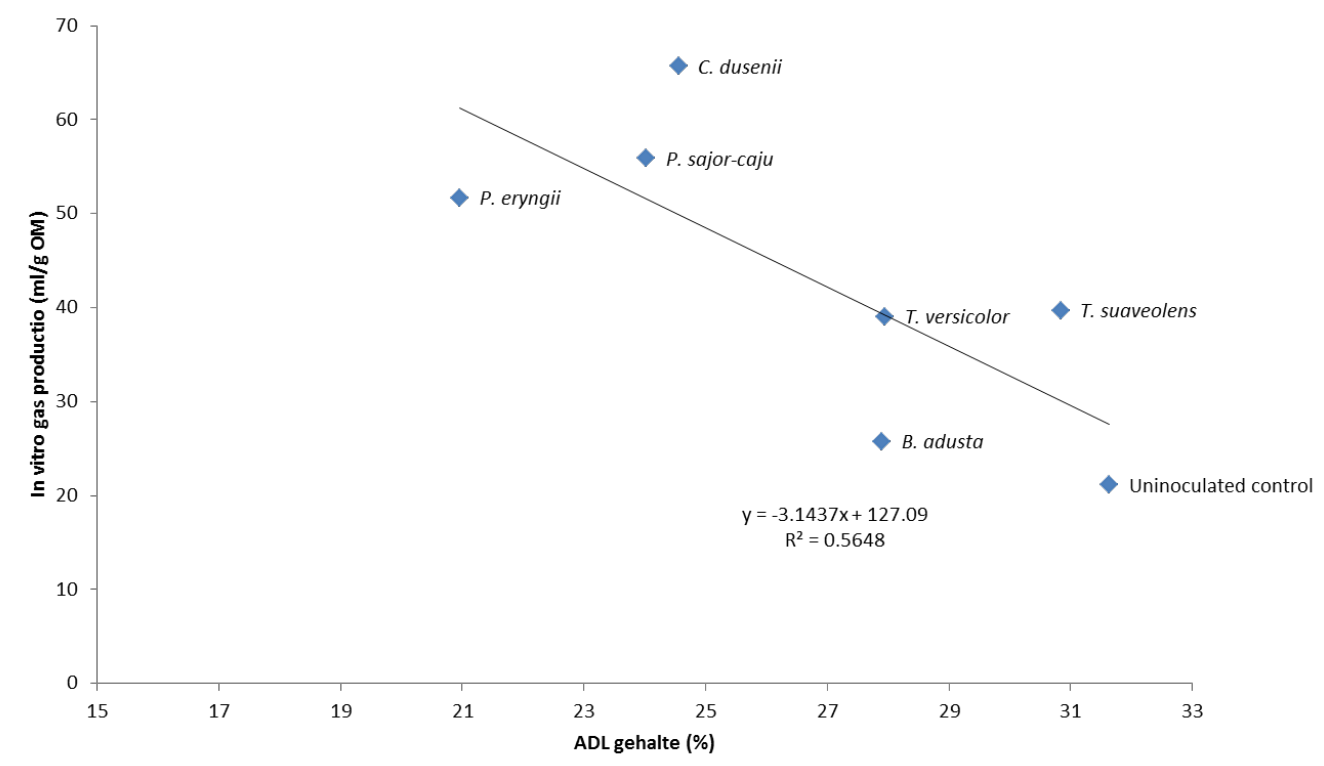

Figuur 5. Relatie tussen lignine-gehalte in de behandelde champost (uitgedrukt als Acid Detergent Lignin (\% ADL) en de productie van biogas uit deze champost.

\subsection{Discussie}

Bovenstaande experimenten laten zien dat de verschillende witrot-schimmels die kunnen groeien op champost in verschillende mate in staat zijn om het ligninegehalte (gemeten als Acid Detergent Lignin) te verlagen. Het lijkt er daarnaast op dat met een verlaging van het ligninegehalte de resterende holocellulose in de champost beter 
toegankelijk wordt voor enzymen die het cellulose en hemicellulose afbreken. Ten opzichte van onbehandelde champost wordt de hoeveelheid suikers (afgeleid uit de geproduceerde hoeveelheid biogas) die door enzymen uit champost kan worden vrijgemaakt ruimschoots verdubbeld. Echter, zelfs na behandeling met witrot-schimmels blijft de hoeveelheid suikers die uit champost kan worden ver achter bij de hoeveelheid suikers die kan worden vrijgemaakt uit tarwestro of zelfs snoeihout. Voor een bio-based toepassing waarin champost gesaccharificeerd moet worden lijkt het geen bijzonder interessante grondstof.

De samenstelling van champost wordt gegeven in Tabel 8. Volgens deze analyse (op bas is van NDF, ADF en $\mathrm{ADL}$ ) bevat een kilo champost op droge stof basis ongeveer 13 gram hemicellulose en 155 gram cellulose. Dat komt neer op 21 gram hemicellulose en 250 gram cellulose $=271$ gram suikers per $\mathrm{kg}$ organische stof. Ter vergelijking; tarwestro bevat in de orde van grootte van $308 \mathrm{~g}$ hemicellulose en 477 gram cellulose per $\mathrm{kg}$ organische stof. Dat komt neer op 785 gram suikers per kg organische stof en levert een gasproductie van ongeveer $200 \mathrm{ml}$ /gram organische stof (Tuyen et al., 2012). Hoewel de hoeveelheid suikers in champost slechts ongeveer een factor 3 lager ligt dan in tarwestro, ligt de gasproductie een factor 10 lager. Na doorgroeiing van de champost met schimmels zoalsPleurotus eryngii Pleurotus sajoxaju of Clitocybula dusenligt de gasproductie op 50-60 ml/gram organische stof. In vergelijking met tarwestro ligt de gasproductie uit witrochimmel doorgroeide champost een factor3-4 lager dan bij tarwestro. De efficientie waarmee suikers uit tarwestro en de suikers uit witrot-schimmel doorgroeide champost worden omgezet ligt daarmee ongeveer gelijk.

Tabel 8. Samenstelling champost zoals afgeleid uit de meetgegevens van Sonnenberg \& Blok (2012)

\begin{tabular}{|c|c|c|c|c|c|c|}
\hline & Droge stof & As & Organische stof & cellulose & hemicellulose & lignine \\
\hline & $\mathrm{kg}$ & $\mathrm{kg}$ & $\mathrm{kg}$ & $\mathrm{kg}$ & $\mathrm{kg}$ & $\mathrm{kg}$ \\
\hline Proef 1 & 1 & 0.385 & 0.615 & 0.161 & 0.015 & 0.142 \\
\hline Proef 2 & 1 & 0.383 & 0.617 & 0.149 & 0.011 & 0.156 \\
\hline Gemiddeld & 1 & 0.384 & 0.616 & 0.155 & 0.013 & 0.149 \\
\hline
\end{tabular}

Kim et al. (2011) hebben in ZuiłKorea de bruikbaarheid van champost als veevoeder onderzocht. De champost die zij voor hun onderzoek gebruikten was gebaseerd op een compost op basis van een grondstoffenmengsel met $80 \%$ rijststro, $14 \%$ slachtkuikenmest2 $\%$ ureumen $4 \%$ calciumcarbonaatNa de teelt van champignons werd de dekaardelaag verwijderd en uit de resterende champost werden de rijststrodelen verzameld. Deze werden gedroogd en gemalen tot kleine deeltjes $100 \mu \mathrm{m}-2 \mathrm{~mm}$ ) en gebruikt voor een test waarbij de rijstrodelen uit de champost in de pens van een koe werden gebracht. Hiervoor werd een zakje (Dacron R1020, Ankom Technology, NY, USA, afmeting $10 \times 25 \mathrm{~cm}$; poriën grootte in de zak $50 \pm 15 \mu \mathrm{m}$ ) gebruikt met ongeveer $10 \mathrm{~g}$ rijststrodelen afkomstig uit champost). Het zakje werd middels een canule in de pens gebracht en daar na enige tijd (maximaal 72 uur) weer uitgehaald. Na het verblijf in de pens werd gekeken naar het verlies aan droge stof, NDF, ruw eiwit enz. Het ruw eiwit gehalte wordt berekend door het stikstofgehalte te vermenigvuldigen met een factor 6.22. Er wordt daarbij geen rekening gehouden dat een flink deel van het stikstof in schimmels niet in de vorm van eiwit, maar bijvoorbeeld in de vorm van chitine aanwezig is.

In vergelijking met gewoon rijststro, liet het rijststro dat uit de champost afkomstig was tijdens het verblijf in de pens enerzijds een groter verlies aan droge stof of ruw eiwit zien en anderzijds een lager verlies aan NDF. Dat is te verklaren doordat het champignonmycelium al een flink deel van het NDF (de vezelfractie waarin cellulose + hemicellulose + lignine aanwezig zijn) heeft geconsumeerd waardoor het voor de pens-microorganismen niet meer beschikbaar is. Het ruw eiwit in het rijststro uit de champost is voor een groot deel afkomstig uit het eiwit en de chitine van het champignonmycelium en wordt door de pens micro-organismen gemakkelijk afgebroken.

Als we met deze kennis kijken naar de biogasproductie in Figuur 5, dan zien we dat de biogasproductie op bas is van champost op ongeveer $20 \mathrm{ml}$ gram organische stof ligt. Na doorgroeïng van de champost met schimmels zoals Pleurotus eryngiiPleurotus sajoxaju of Clitocybula dusenligt de gasproductie op 50-60 m/ gram organische stof. Een deel van deze toename in biogasproductie zou wel eens het gevolg kunnen zijn van de aanwezigheid van het extra schimmelmateriaal als gevolg van de kolonisatie door bovengenoemde schimmels en slechts in mindere mate het gevolg kunnen zijn van het vrijmaken van extra koolhydraten. 


\section{Champost als bron van enzymen}

Om suikers te kunnen vrijmaken uit lignocellulose-houdend materiaal zijn enzymen nodig en deze enzymen zijn in ruime mate aanwezig in een niet-doodgestoomde champost (Ayala et al., 2011). Om die reden is onderzocht of enzym-extract uit champost in staat is om suikers vrij te maken uit lignocellulose-houdend substraat.

\subsection{Maken van een enzymextract.}

Champost (250 gram) werd gemengd met $375 \mathrm{ml}$ natriumcitraat buffer (50 mM, pH 5.3) en gedurende 30 minuten op $230 \mathrm{rpm}$ geschud op een rotary shaker bij kamertemperatuur. De mix werd gefiltreerd over een dubbele laag kaasdoek en het filtraat is gecentrifugeerd om te zorgen dat er geen vaste deeltjes meer in het extract zitten. Om te kijken hoeveel eiwit geëxtraheerd is, is er een BCAbepaling (Thermo Scientific Pierce BCA protein reagent kit) gedaan op het extract. Hiermee is vast gesteld dat er $4 \mathrm{mg} / \mathrm{ml}$ eiwit in het extract zit. Dit zijn niet alleen enzymen, maar kunnen ook andere eiwitten zïn.

\subsection{Bepalen van de enzymactiviteit}

Voor het vaststellen van de enzymactiviteit is gebruik gemaakt van geautoclaveerd tarwestro dat niet met witrot schimmels werd behandelen tarwestro dat gedurende 8 weken werd doorgroeid mee. subvermisporaf $L$. edodes Dit tarwestro is gedroogd bij $70^{\circ} \mathrm{C}$ en gemalen $(1 \mathrm{~mm})$ voøfgaand aan dœnzym activiteit bepalingen. Aan 2 gram biomassa is $4 \mathrm{ml}$ champost extract $(4 \mathrm{mg} / \mathrm{ml}=16 \mathrm{mg}$ eiwit) en $16 \mathrm{ml}$ natriumcitraat buffer $(50 \mathrm{mM}, \mathrm{pH} \mathrm{5.3)}$ toegevoegd. Bij de controle is $20 \mathrm{ml}$ natriumcitraat buff (50 mM, pH 5.3) toegevoegd aan 2 gram biomassa om uit te sluiten dat de biomassa nog een restant enzymen bevat.

$\mathrm{Na}$ 0, 4, 8, 12, 24, 48 en 72 uur zijn monsters genomen van het reactiemengseleஜe zijngeanalyseerd op aanwezigheid varglucose met de Bglucose (GOPOD) kit (juc 07/11) van megazyme. Voor een schatting vache cellulase activiteit in het enzym extract is de hoeveelheid vrijgemaakte glucose bepaald. Cellulase activiteit is uitgedrukt als mg vrijgemaakte glucose per gram biomassa. Voor eechatting van hemicellulase activiteit in het enzym extract is de hoeveelheid vrijgemaakte xylose bepaald met behulp van ekglDse kit (Kxylose 11/12) van megazyme. Hemicellulase activiteit is uitgedrukt als mg vrijgemaakte xylose per gram hemicelluilosłe biomassa. De samenstelling van de substraten voor de bepaling van de enzymactiviteiłeafgeleid uit de resultaten van de analyse met de Van Soest method(eTabel 9).

Tabel 9. Samenstelling van tarwestro en tarwestro dat 8 weken doorgroeid is met Lentinula edodes of Ceriporiopsis subvermispora.

\begin{tabular}{|l|l|l|l|}
\hline Component (g/kg droge stof) & Onbehandeld & \multicolumn{1}{l|}{ L. edodes } & \multicolumn{1}{l|}{ C. subvermispora } \\
\hline Cellulose & 440.3 & 518.6 & 490.2 \\
\hline Hemicellulose & 321.5 & 132.8 & 87.2 \\
\hline Lignine (ADL1) & 75.3 & 29.4 & 17.4 \\
\hline
\end{tabular}

${ }^{1}$ ligninegehalte is bepaald door middel van de acid detergent lignin (= ADL) bepaling

\subsubsection{Cellulase activiteit}

De resultaten van een analyse op cellulase activiteit worden weergegeven in Figulu 6nze experimenten bleken de enzymen uit de champost in staat om slets 8 tot $12 \mathrm{mg}$ glucose vrij te maken uit de 44€520 mg cellulose die in het substraat aanwezig was. Dat is slechts $2 \%$ van het in potentie aanwezige glucose in het bromoedelijk is dit omdat dan alletoegankelijkecellulose op is en de schimmel ruimtenoet creëren om bij de overige cellulose te komen of uit andere suikers (zoals hemicelbse) zijn energie moet halen. 


\section{vrijgemaakte glucose}

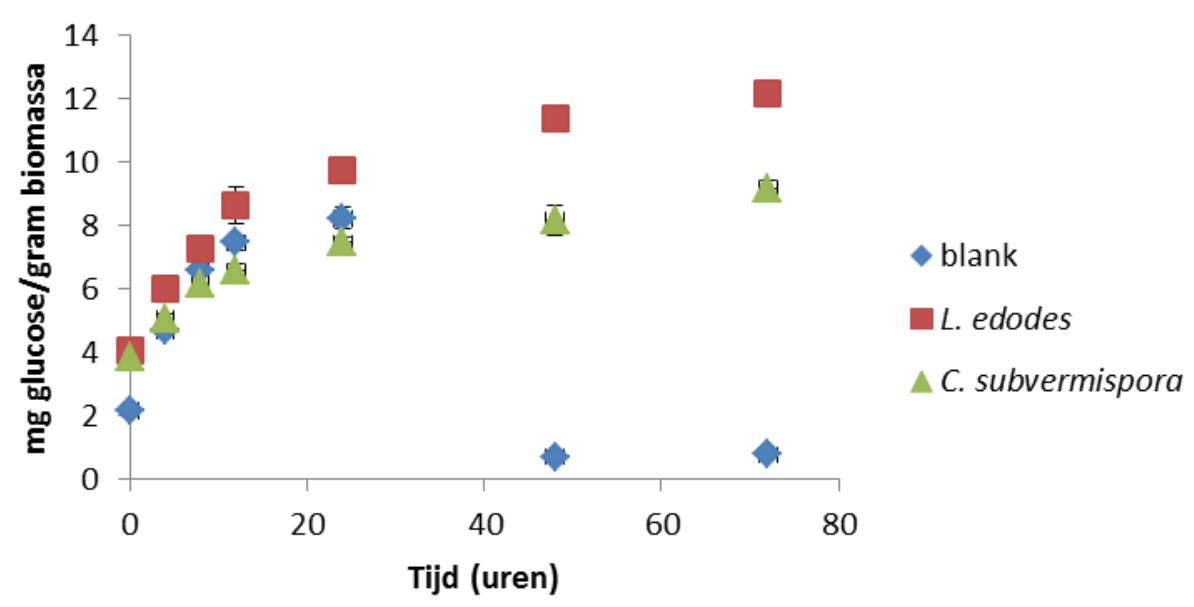

Figuur 6. Vrijmaking van glucose uit tarwestro, al dan niet behandeld met de witrot-schimmels Lentinula edodes of Ceriporiopsis subvermispora. Blank = niet behandeld tarwestro.

Patyshakuliyeva en collega's (2015) laten zien dat er na de productie van 2 vluchten champignons nog ruime cellulase activiteit in de compost aanwezig is. Echter, hun enzymbepaling maakt gebruik van het zeer goed oplosbare carboxy-methyl-cellulose als substraat. Het cellulose in tarwestro (zoals dat in onze enzymtest is gebruikt) is niet oplosbaar en beschermd door lignine en hemicellulose. Waarschijnlijk zit daar het grote verschil tussen haar resultaten en de hier gepresenteerde resultaten.

\subsubsection{Hemicellulase activiteit}

De resultaten van een analyse op hemicellulase (= xylanase) activiteit worden weergegeven in Figuur 7. De xylanases in het extract uit champost zijn niet in staat om xylose vrij te maken uit het onbehandelde tarwestro.. In schimmelbehandeld tarwestro daarentegen kunnen de enzymen in het extract uit champost wel zorgen voor het vrijmaken van xylose uit hemicellulose. De resultaten zijn uitgedrukt per gram hemicellulose in het tarwestro. De

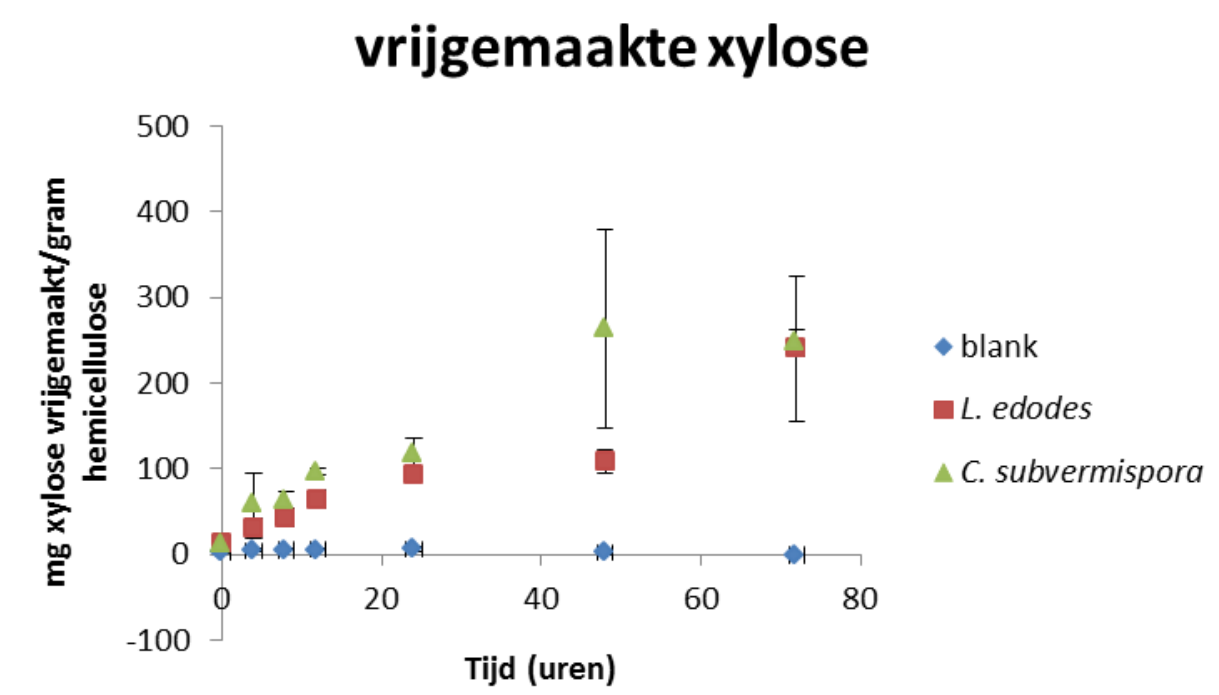

Figuur 7. Vrijmaking van xylose uit tarwestro, al dan niet behandeld met de withrot-schimmels Lentinula edodes of Ceriporiopsis subvermispora. Blank = niet behandeld tarwestro. 
totale hoeveelheid hemicellulose in schimmelbehandeld tarwestro is lager dan in onbehandeld tarwestro (Tabel 9), maar de hemicellulose die nog aanwezig is, is wel beter beschikbaar voor enzymen in champost extract. Naast hemicellulose hebberk. edodesen $C$. subvermisporavoornamelijk lignine afgebroken. Daarom lijkt het erop dat de enzymen in champost extract alleen de hemicellulose kunnen afbreken naar xylose wanneer er geen lignine meer in de weg zit. Het is belangrijk om te melden dat hemicellulose niet alleen uit (maar ook uit andere C5uikers zoals arabinose, mannose, galactose of rhamnose bestaat. Deze suikers zijn hier niet gemeten, maar er is gekozen om xylose als maat voor hemicellulose afbraak door enzymen te nemea. 85\% van de 5 suikers in hemicelluse van tarwestro is xylose (Jurak, thesis 2015Daarnaast is de bepaling van totale hemicellulose met de Van Soest methode totaal anders dan de bepaling van vrije xylose. Vergelijkingen tussen hemicellulose gehalte en xylose gehalte moeten daarom voorzlatig gemaakt worden. Het zou beter zijn om het substraat volledig te hydrolyseren, dan de totale hoeveelheid xylose te meten in het materiaal en dit te vergelijken met vrijgemaaktes na incubatie met enzymen.

Jurak en collega's (2015) onderzochten dæfbraak van in compost aanwezige hemicellulose door champignon. Zij kwamen tot de conclusie dat champignon niet in staat was om hemicellulose volledig af te breken. Hemicelliulose tarwestro heeft een veel complexere structuur dan cellulose enviøornameijk opgebouwd uitketens vande suiker xylosemet korte zijketens van de suikearabinoseen glucuronzuur. Daarnaast zitten er op sommige plekken nog kleine acetyłgroepen aan het xylose enefrulazuuraan het arabinose. Jurak en collega's kwamen tot detdakking dat champignon niet in staat was om de gedeelten van het hemicellulose af te breken waar de arabinose groepen en het glucuronzuur aan het hemicellulose gebonden zijn. Een volledige afbraak van hemicellulose uit tarwestro is daardoor niet mogelijk.Dat beperkt uiteraard de bruikbaarheid van het enzymextract.

\section{$5.3 \quad$ Discussie}

De resultaten van de extractie van enzymen uit champost laat zien dat slechts weinig bruikbare cellulase activiteit in champost aanwezig is, maar dat deze enzymen moeite hebben om cellulose in onopgeloste vorm af te breken. Dat beperkt de moge lijkheden voor gebruik. De enzymen uit champost vertonen een aanzienlijk grotere hemicellulase activiteit. Echter, literatuuronderzoek leert dat deze enzymen niet in staat zijn om hemicellulose dat zijketen van arabinose en glucuronzuur bevat af te breken.

Enzympreparaten met cellulase of hemicellulase worden tegenwoordig tegen vrij lage kosten op de markt aangeboden. Er worden hogere prijzen gevraagd voor enzymen met bijzondere specificiteiten. In dat licht is het de vraag of enzymen die geëxtraheerd worden uit champost enige toegevoegde waarde op de markt zullen vertonen. 


\section{Champost als substraat component in de teelt van koningsoesterzwam (Pleurotus eryngii)}

Zoals aangetoond in hoofdstuk 3, i\$ leurotus eryngiigoed in staat om de lignine fractie in champost te verlagen (Tabel 6) en daardoor de toegankelijkheid van resterende voedingstoffen in de champost te verhogen (Tabel 7). Om deze reden is een experiment uitgevoerd waarin champost is gebruild aen substraat component voor de teelt van Pleurotus eryngiiNormaliter wordt Pleurotus eryngii geteeld op een substraat dat is samengesteld uit zaagsel, een voedingssupplement en water. Dit substraat wordt gepasteuriseerd bij ongeveer ${ }^{\circ} \mathrm{L}$ en na afkoelen gent met broed vanPleurotus eryngiVervolgens wordt het beënte substraat in $3 \mathrm{~kg}$ porties afgevuld in plastic zakken met een filter voor gasuitwisseling.

\subsection{Karakterisatie van de gebruikte champost .}

Ten behoeve van deze teeltproef is chrpost opgehaald bij een teler. De gebruikte champost was niet gestoomd voorafgaand aan het gebruik als substraatcomponent. Het droge stof gehalte van de champost werd bepaald aloor mengmonsters te nemen en van elk mengmonster het droge stof gehalte te aton door droging bij 105C. De gebruikte champost had een droge stof gehalte van $413 \mathrm{~g} / \mathrm{kg}$ versgewicht (standaard deviatie $8.8 \mathrm{~g} / \mathrm{kg} \phi t a a l$ stikstof gehalte van de champost werd vastgesteld op $2.4 \%$ van de droge stof.

\subsection{Substraatsamenstellingen}

Een overzich van de geteste substraatsamenstellingen wordt gegeven in Tabel Het substraat voor Pleurotus eryngii heeft bij voorkeur een vochtgehalte van ongeveer $60 \%$ en een totaal stikstofgehalte van $1.2 \%$. Echter, het stikstof dat aanwezig is in champost is voœen groot deel ingevangen in humusbestanddelen in de compost en daardoor niet biologisch beschikbaarBij behandelingen $\mathrm{t} / \mathrm{m} 4$ is de champost daarom in de receptuur verwerkt zonder acht te slaan op het resulterende totaal stikstofgehalte. De hoeveelheip/stement in het substraat is daarbij telkens gelijk gehouden. Bij behandelingen 5 en 6 daarentegen is het totaal stikstofgehalte op 1.2\% stikstof gehouden. Ter vergelijking is een behandeling toegevoegd waarin alle zaagsel is vervangen door champost

Tabel 10. Globale samenstelling van de geteste substraten.

\begin{tabular}{|c|c|c|c|c|c|c|}
\hline Beh. & Substraat met & $\begin{array}{c}\text { Vocht } \\
\text { gehalte }\end{array}$ & $\begin{array}{l}\text { Totaal stikstof } \\
\text { (\% vd droge stof) }\end{array}$ & $\begin{array}{l}\text { Zaagsel } \\
(\mathrm{kg})\end{array}$ & $\begin{array}{l}\text { Champost } \\
(\mathrm{kg})\end{array}$ & $\begin{array}{l}\text { Supplement } \\
\text { (kg) }\end{array}$ \\
\hline 1 & $0 \%$ champost & $60 \%$ & 1.21 & 11.209 & 0 & 3.755 \\
\hline 2 & $9 \%$ champost & $61 \%$ & 1.32 & 10.200 & 1.009 & 3.755 \\
\hline 3 & $18 \%$ champost & $61 \%$ & 1.44 & 9.191 & 2.018 & 3.755 \\
\hline 4 & $27 \%$ champost & $62 \%$ & 1.57 & 8.182 & 3.026 & 3.755 \\
\hline 5 & $18 \%$ champost & $60 \%$ & 1.20 & 9.191 & 2.018 & 4.080 \\
\hline 6 & $27 \%$ champost & $60 \%$ & 1.20 & 8.182 & 3.026 & 4.293 \\
\hline 7 & $100 \%$ champost & $60 \%$ & 2.30 & 0 & 12.890 & 5.604 \\
\hline
\end{tabular}

De verschillende substraten werden afgevuld in $3 \mathrm{~kg}$ porties in plastic zakken met een filter voor gasuitwisseling. Per behandeling (substraat type) werden 8 zakken afgevuld. Vervolgens werden de substraten gepasteuriseerd door ze te stomen. Na iets meer dan 4 uur stomen was de temperatuur van het substraat in de zakken gestegen tot boven $95^{\circ} \mathrm{C}$. Vervolgens liep de temperatuur in 4 uur tijd geleidelijk op tot $99.9^{\circ} \mathrm{C}$. De stoom toevoer werd vervolgens gestopt. Na ruim 40 uur waren de substraten weer afgekoeld tot $22^{\circ} \mathrm{C}$. 


\subsection{Teeltverloop}

Nadat de substraten voldoende waren afgekoeld, werden de zakken op donderdag 1 oktober 2015 in een laminar flow kast geënt met 30 gram broed per zak. Vervolgens werden de zakken in een geklimatiseerde ruimte geplaatst bij een luchttemperatuur van $23^{\circ} \mathrm{C}\left(\mathrm{RV}\right.$ en $\mathrm{CO}_{2}$ niet geregeld). De myceliumgroei vond plaats in het donker. Figuur 8 toont de doorgroeiing van de diverse substraten op dag 14 van de mycelium doorgroeifase. Er is een duidelijk
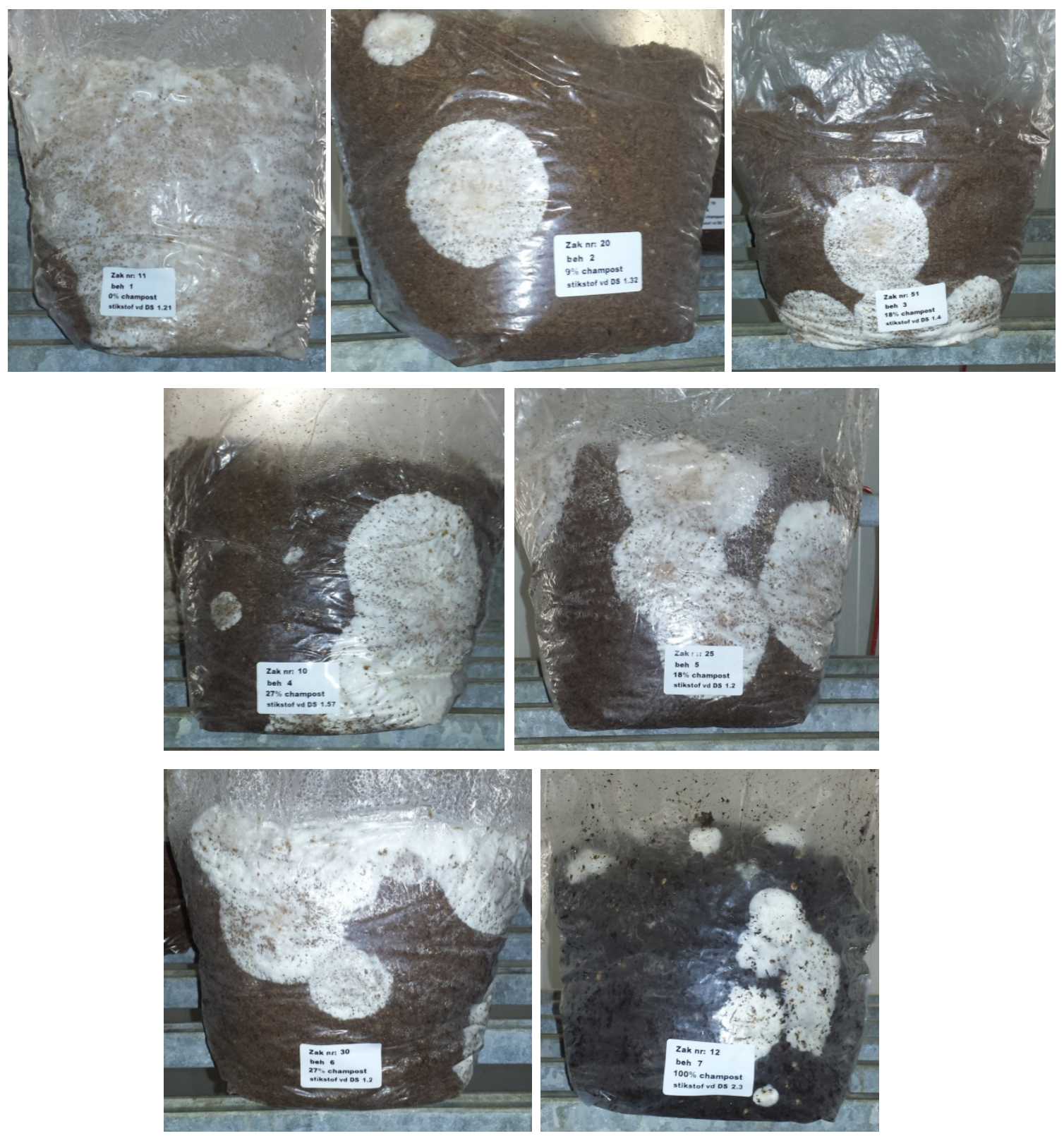

Figuur 8. Mate van doorgroeiing van de substraten in Tabel 10 na twee weken incubatie bij $23^{\circ} \mathrm{C}$.

verschil te zien tussen het substraat waar geen champost aan werd toegevoegd en de overige substraten met meer of minder toegevoegde champost. Deze vertraging in de kolonisatie van het substraat indien champost werd toegevoegd was enigszins verrassend. In eerdere proeven zoals beschreven in paragraaf 2.3.1. was geen indicatie gevonden voor een remming van de myceliumgroei door champost. Het belangrijkste verschil tussen de champost die gebruikt werd voor de proeven in paragraaf 2.3.1. en de champost die gebruikt werd voor de hier beschreven teeltproef, was dat de champost voor de proeven in paragraaf 2.3.1. voorafgaand aan gebruik gedroogd was bij 
Tabel 11. Overzicht van de belangrijkste karakteristieken voor teelt van Pleurotus eryngii met champost als substraat component.

\begin{tabular}{|c|c|c|c|c|}
\hline Behandeling & $\begin{array}{c}\text { Aantal dagen nodig } \\
\text { voor substraat } \\
\text { kolonisatie }\end{array}$ & $\begin{array}{l}\text { Aantal dagen tot } \\
\text { eerste oogstdag }\end{array}$ & $\begin{array}{c}\text { Aantal dagen tussen } \\
\text { afventileren en eerste } \\
\text { oogstdag }\end{array}$ & $\begin{array}{c}\text { Gemiddelde } \\
\text { opbrengst } \\
\text { (gram/zak) }\end{array}$ \\
\hline $\begin{array}{c}1 \\
0 \% \text { champost } \\
1.21 \% \mathrm{~N} \\
\end{array}$ & $\begin{array}{c}34.0 \\
\text { (s.d. 0) }\end{array}$ & $\begin{array}{c}48.0 \\
\text { (s.d. 1.2) }\end{array}$ & $\begin{array}{c}14.0 \\
\text { (s.d. 1.2) }\end{array}$ & $\begin{array}{c}662 \\
\text { (s.d. 52) }\end{array}$ \\
\hline $\begin{array}{c}2 \\
9 \% \text { champost } \\
1.32 \% \mathrm{~N} \\
\end{array}$ & $\begin{array}{c}46.3 \\
\text { (s.d. 4.7) }\end{array}$ & $\begin{array}{c}61.6 \\
\text { (s.d. 3.6) }\end{array}$ & $\begin{array}{c}15.4 \\
\text { (s.d. 1.5) }\end{array}$ & $\begin{array}{c}710 \\
\text { (s.d. 110) }\end{array}$ \\
\hline $\begin{array}{c}3 \\
18 \% \text { champost } \\
1.44 \% \mathrm{~N} \\
\end{array}$ & $\begin{array}{c}48.0 \\
\text { (s.d. 6.3) }\end{array}$ & $\begin{array}{c}63.0 \\
\text { (s.d. 6.3) }\end{array}$ & $\begin{array}{c}15.0 \\
\text { (s.d. 0) }\end{array}$ & $\begin{array}{c}643 \\
\text { (s.d. 109) }\end{array}$ \\
\hline $\begin{array}{c}4 \\
27 \% \text { champost } \\
1.57 \% \mathrm{~N} \\
\end{array}$ & $\begin{array}{c}50.0 \\
\text { (s.d. 3.7) }\end{array}$ & $\begin{array}{c}63.4 \\
\text { (s.d. 5.5) }\end{array}$ & $\begin{array}{c}13.4 \\
\text { (s.d. 6.0) }\end{array}$ & $\begin{array}{c}639 \\
\text { (s.d. 88) }\end{array}$ \\
\hline $\begin{array}{c}5 \\
18 \% \text { champost } \\
1.2 \% \mathrm{~N} \\
\end{array}$ & $\begin{array}{c}42.6 \\
\text { (s.d. 3.6) }\end{array}$ & $\begin{array}{c}57.5 \\
\text { (s.d. 3.6) }\end{array}$ & $\begin{array}{c}14.9 \\
\text { (s.d. 1.0) }\end{array}$ & $\begin{array}{c}699 \\
\text { (s.d. 116) }\end{array}$ \\
\hline $\begin{array}{c}6 \\
27 \% \text { champost } \\
1.2 \% \mathrm{~N} \\
\end{array}$ & $\begin{array}{c}43.5 \\
\text { (s.d. 5.3) }\end{array}$ & $\begin{array}{c}58.0 \\
\text { (s.d. 6.3) }\end{array}$ & $\begin{array}{c}14.5 \\
\text { (s.d. } 2.4)\end{array}$ & $\begin{array}{c}667 \\
\text { (s.d. 170) }\end{array}$ \\
\hline $\begin{array}{c}7 \\
100 \% \text { champost } \\
2.3 \% \mathrm{~N} \\
\end{array}$ & $\begin{array}{c}44.4 \\
\text { (s.d. 3.6.) }\end{array}$ & $\begin{array}{c}60.8 \\
\text { (s.d. 3.1.) }\end{array}$ & $\begin{array}{c}16.4 \\
\text { (s.d. } 0.5)\end{array}$ & $\begin{array}{c}429 \\
\text { (s.d. 66) }\end{array}$ \\
\hline
\end{tabular}

$70^{\circ} \mathrm{C}$ en droog bewaard werd tot gebruik. De champost die gebruikt werd voor de teeltproef is niet vooraf gedroogd. Indien champost in de praktijk ooit gebruikt zomorden als substraat voor de teelt van andere paddenstoelen, zou ze immers ook niet gedroogd worden.

De belangrijkste karakteristieken van de teelt valleurotus eryngimet champost als substraat component staan weergegeven in Tabel 11 (de ruwe data riterug te vinden in Annex 1). Substraat van behandeling 1 (geen champost toegevoegd) was na 34 dagen voldoende doorgroeid om te kunnen worden afgeventileerd. De overige substraten hadden daar aanzienlijk langer voor nodig, varierend van gemiddeld 43 tot gmiddeld 50 dagen. Bij behandeling 1 waren alle 8 herhalingen op dezelfde dag voldoende doorgroeid om afgeventileerd te worden. Bij de behandelingen met een gedeelte champost in het substraat waren tussen de 8 herhalingen binnen de behandeling aanzienlijkeverschillen te zienEr was relatief weinig uitval door infectie; alleen bij behandelingen 3 en 4 ging elk 1 op de 8 zakken substraat verloren als gevolg van infectie. De verschillen in de tijdsduur die nodig was voor het koloniseren van het substraat bealen voor het overgrote deel de tijdsduur die nodig tot de eerste oogstdag. Substraten die werden afgeventileerd produceerden na 13 tot 16 dagen oogstrijpe koningsoesterzwammen, ongeacht de substraatsamenstelling.

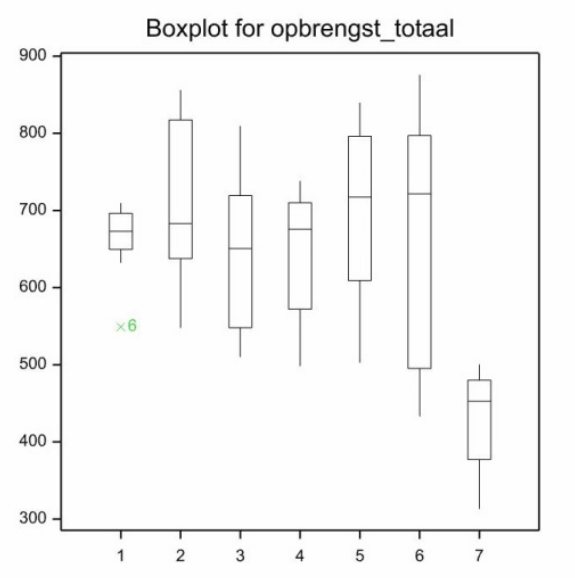

Figuur 9. Boxplot voor de opbrengst in de verschillende substraten. 
Vervanging van een gedeelte van het zaagsel in het substraat door champost had geen effect op de gemiddelde opbrengst aan paddenstoelen. Echter, zoals de boxplot in Figuur 9 laat zien, introduceerde de vervanging van zaagsel door champost wel veel meer variabiliteit in de opbrengsten. Vervanging van alle zaagsel door champost resulteerde in een statistisch significante verlaging van de opbrengst (ANOVA, $p=0.05$ ).

De geproduceerde paddenstoelen leken niet veel van elkaar te verschillen voor wat betreft kwaliteit. Figuur 9 toont willekeurig gekozen foto's van de paddenstoelen van de verschillende behandelingen. Op veel van de

koningsoesterzwammen waren donkere vlekken te zien. Die duiden mogelijk op een aantasting met bacteriën. Of dit ook werkelijk zo was, is niet onderzocht.
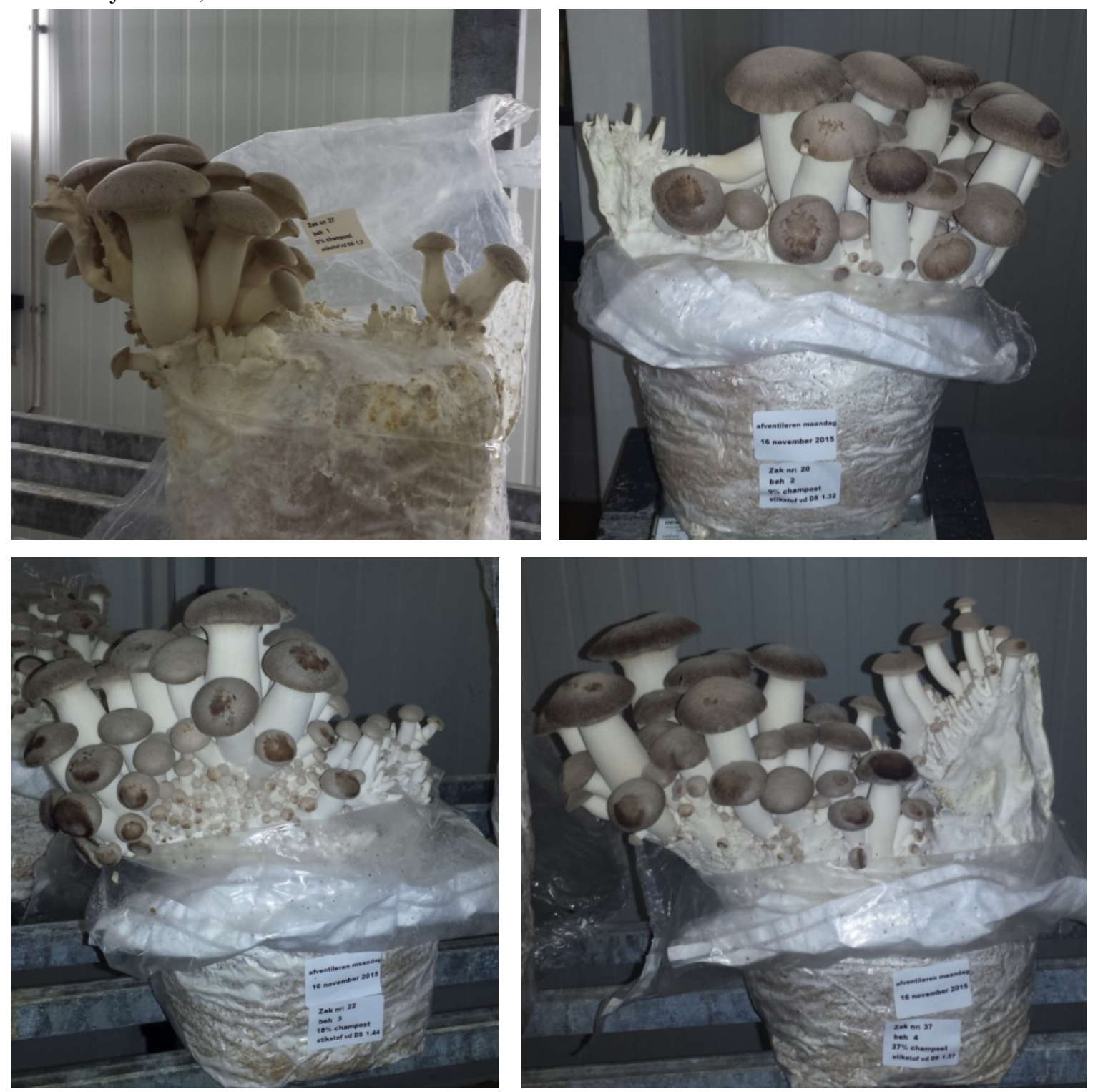

Figuur 10. Voorbeelden van de geproduceerd paddesntoelen van behandelingen 1 tot en met 4.

\section{$6.4 \quad$ Conclusie}

Het teeltexperiment toont aan dat het mogelijk is om een gedeelte van het zaagsel in het substraat voor koningsoesterzwam Pleurotus eryngÿte vervangen door champost, zonder dat dat ten koste gaat van opbrengst of paddenstoelkwaliteitEchter, het volledig vervangen van het zaagsel in het substraat door champost leidt tot een reductie van de opbrengst meB5\%. 

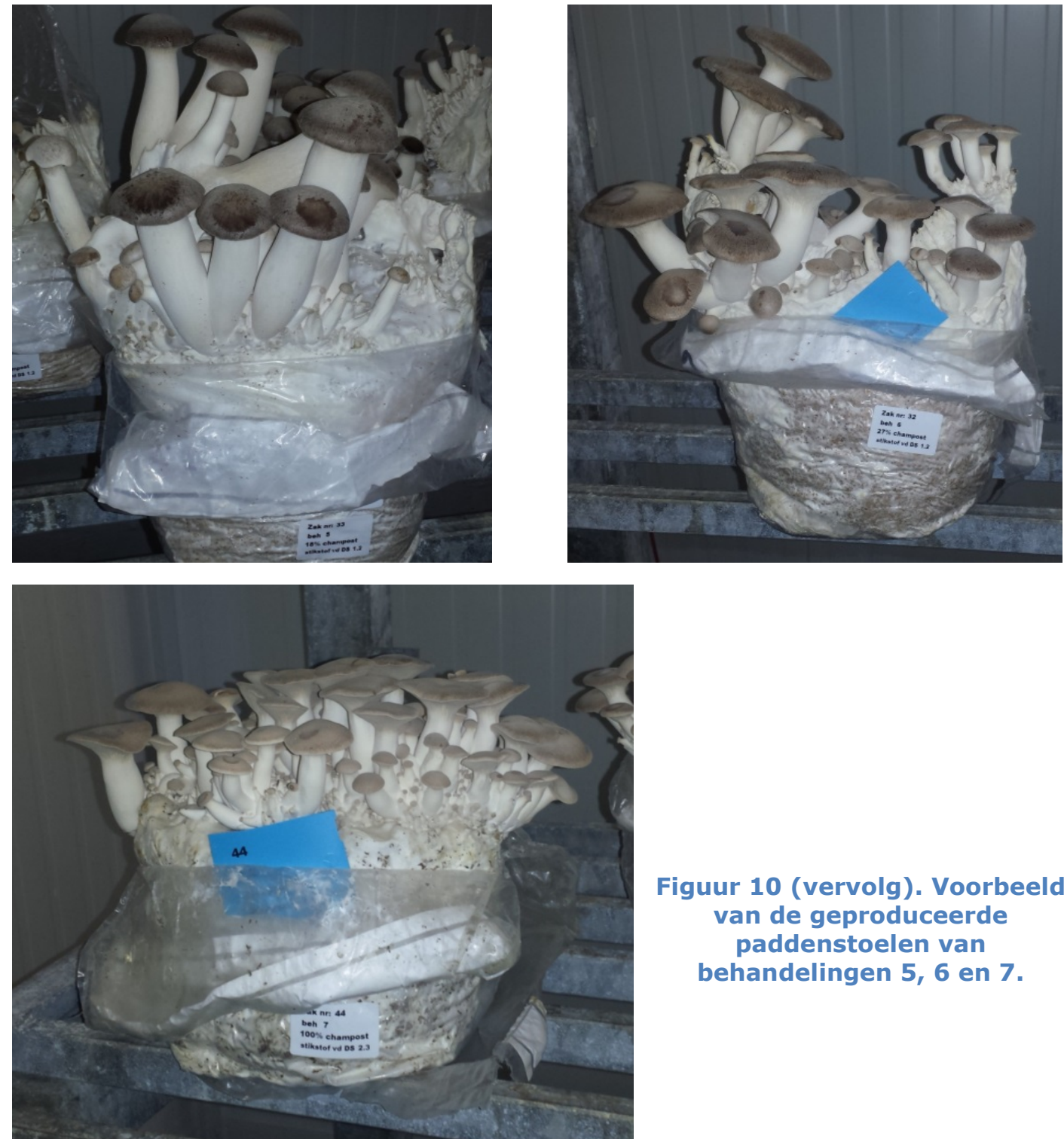

Figuur 10 (vervolg), Voorbeeld van de geproduceerde paddenstoelen van behandelingen 5, 6 en 7 .

Terwijl het gedeeltelijk vervangen van zaagsel in het substraat door champost geen effect heeft op de opbrengst aan paddenstoelen, heeft het een aanzienlijk effect op de tijd die nodig is om het substraat te laten koloniseren door de schimmel. Als een gedeelte van het zaagsel in het substraat werd vervangen door champost duurde het bijna anderhalf maal zo lang voordat het substraat voldoende doorgroeid was om te kunnen afventileren. Dit remmend effect was op basis van de lineaire groeis nelheid op gesteriliseerde champost (Tabel 6) niet voorzien. De resultaten die gepresenteerd zijn in Tabel 6 zijn behaald op een champost-substraat dat is gemaakt door champost eerst te drogen, vervolgens te bevochtigen en daarna te steriliseren bij $121^{\circ} \mathrm{C}$. Dat is een werkwijze die weliswaar de voedingswaarde van de champost voor de schimmels netjes in kaart brengt, maar die tevens ver van de praktijk staat. Om die reden werd de champost die werd toegevoegd aan het substraat voor koningsoesterzwam niet voorbewerkt. Blijkbaar zorgt het drogen en steriliseren van champost voor een verwijdering van de remmende factoren die we waarnemen indien we champost onbewerkt aan het substraat voor koningsoesterzwam toevoegen. 


\section{Geciteerde literatuur}

- Ayala, M, González-Muñoz S.S., Pinos-Rodríguez J.M, Vázquez C., Meneses M, Loera O., Mendoza G.D. (2011), Fibrolytic potential of spent compost of the mushroom Agaricus bisporus to degrade forages for ruminants. African Journal of Microbiology Research, 2011. 5(3): p. 241-249.

- Chen, Y., Chefetz, B., Rosario, R., van Heemst, J. D. H., Romaine, C. P. and Hatcher, P. G (2000) Chemical Nature and Composition of Compost during Mushroom Growth. Compost Science and Utilization, 2000. 8(4): p. 347-359.

- Cone, J.W., van Gelder, A., Visscher, G.J.W., Oudshoorn, L., (1996) Influence of rumen fluid and substrate concentration on fermentation kinetics measured with a fully automated time related gas production apparatus. Anim. Feed Sci. Technol. 61, 113-128.

- Gonani, Z., H. Riahi, and K. Sharifi (2011) Impact of using leached spent mushroom compost as a partial growing media for horticultural plants. Journal of Plant Nutrition, 34(3): p. 337-344.

- Gerrits, J.P.G., (1994) Composition, use and legislation of spent mushroom substrate in the Netherlands. Compost Science \& Utilization, 2(3): p. 24-30.

- Gerrits, J.P.G. (1997) Ringonderzoek Champost 1996. De Champignoncultuur 41 (3): p. 99-101.

- Gerrits, J.P.G., H.C. Bels-Koning, and F.M Muller (1967) Changes in compost constituents during composting, pasteurisation and cropping. Mushroom Science 6: pp. 225-243.

- Gerrits, J.P.G. (1969) Organic compost constituents and water utilized by the cultivated mushroom during spawn run and cropping. Mushroom Science 7: pp. 111-126.

- $\quad$ liyama, K. B.A Stone, and B.J. Macauley (1994) Compositional changes in compost during composting and growth of Agaricus bisporus. Applied and Environmental Microbiology 60 (5): p. 1538-1546.

- Jurak E. (2015) How mushrooms feed on compost: conversion of carbohydrates and lignin in industrial wheat straw based compost enabling the growth ofgaricus bisporusPhD thesis WageningenUR. Chapter 4; Accumulation of recalcitrant xylan in mushroom compost is due to a lack of xylan substituent removing enzyme activities ofAgaricus bisporusPage 55.

- Kim, Y.I., et al., Yield, nutrient characteristics, ruminal solubility and degradability of spent morstir (Agaricus bisporu\$ substrates for ruminants AsianAustralasian Journal of Animal Sciences, 20124(11): p. 1560-1568.

- Patyshakuliyeva A. (2015) Unraveling the mystery of commercial cultivation of Agaricus bisporus; plant biomass utilization and itæffect on mushroom production. PhD Thesis, WageningenUR.

- Sonnenberg A.S.M. \& Blok C. (2012) Inpattput Fase II (PT projectnummer 13887). Rapport nummer 2012-7.

- $\quad$ Straatsma, G.(2006) Spent mushroom substrate, SMS; "livestock manure" according to the Nitrate Directive or compost?

- $\quad$ Szmidt, R.A.K. and C. Chong, Uniformity of spent mushroom substrate (SMS) and factors in applying recommendations for use.Compost Sci. Util., 1995.3(1): p. 64-71.

- Ten Have R., Wijngaard H., Ariłsonenburg N., Straatsma G. \& Schaap P, (2003) Lignin Degradation by Agaricus bisporus accounts for a $30 \%$ increase in bioavailable holocellulose during cultivation on compost. J. Agric. Food Chem. 51, 22422245

- $\quad$ Tuyen, V.D., Cone, J.W., Baars, J.J.P., Sonnenberg, A.S.M., Hendriks, W.H. (2012) Fungal strain and incubation period affect chemical composition and nutrient availability of wheat straw for rumen fermentation. Bioresource Technology 111, pp. 33642

- Van Soet, P.J., McQueen, R.W., 1973The chemistry and estimation of fibreProc. Nutr. Soc. 32, $123-$ 130.

- Van Soest, P.J., Robertson, J.B., Lewis, B.A., 199Methods for dietary fiber, neutral detergent fiber, and nonstarch polysaccharides in relation to animal nutritioh. Dairy Sci. 74, 35833597.

- Zhu, Y., Roestel van, A(2002) Oriënterende studie naar de mogelijkheden voor hergebruik van champost. Rapport2002-20. 


\section{Bijlage I.}

\section{Meetgegevens teeltproef met champost als vervanger voor zaagsel .}

\begin{tabular}{|c|c|c|c|c|c|c|c|}
\hline Beh. & $\begin{array}{l}\text { Aandeel } \\
\text { champost in } \\
\text { substraat }\end{array}$ & $\begin{array}{l}\frac{1}{\Phi} \\
\frac{\mathrm{D}}{\overline{\mathrm{N}}} \\
\frac{\mathrm{I}}{\mathrm{b}}\end{array}$ & 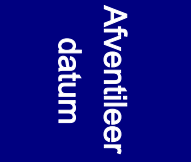 & $\begin{array}{c}\text { \# dagen } \\
\text { substraat } \\
\text { kolonisatie }\end{array}$ & $\begin{array}{c}\text { eerste } \\
\text { oogstdag }\end{array}$ & $\begin{array}{l}\text { \# dagen tussen } \\
\text { afventileren en } \\
\text { eerste oogstdag }\end{array}$ & $\begin{array}{l}\text { Opbrengs } \\
\text { (gram/zak) }\end{array}$ \\
\hline \multirow{8}{*}{1} & \multirow{8}{*}{$0 \%$} & 1 & 3112015 & 34 & 47 & 13 & 667 \\
\hline & & 2 & 3112015 & 34 & 47 & 13 & 632 \\
\hline & & 3 & 3112015 & 34 & 48 & 14 & 670 \\
\hline & & 4 & 3112015 & 34 & 49 & 15 & 710 \\
\hline & & 5 & 3112015 & 34 & 47 & 13 & 693 \\
\hline & & 6 & 3112015 & 34 & 49 & 15 & 549 \\
\hline & & 7 & 3112015 & 34 & 47 & 13 & 676 \\
\hline & & 8 & 3112015 & 34 & 50 & 16 & 700 \\
\hline \multirow{8}{*}{2} & \multirow{8}{*}{$9 \%$} & 1 & 16112015 & 47 & 61 & 14 & 825 \\
\hline & & 2 & 9112015 & 40 & 57 & 17 & 672 \\
\hline & & 3 & 16112015 & 47 & 62 & 15 & 856 \\
\hline & & 4 & 16112015 & 47 & 63 & 16 & 695 \\
\hline & & 5 & 16112015 & 47 & 62 & 15 & 664 \\
\hline & & 6 & 9112015 & 40 & 58 & 18 & 548 \\
\hline & & 7 & 16112015 & 47 & 61 & 14 & 810 \\
\hline & & 8 & 24112015 & 55 & 69 & 14 & 611 \\
\hline \multirow{7}{*}{3} & \multirow{7}{*}{$18 \%$} & 1 & 16112015 & 47 & 62 & 15 & 726 \\
\hline & & 2 & 9112015 & 40 & 55 & 15 & 543 \\
\hline & & 3 & 9112015 & 40 & 55 & 15 & 510 \\
\hline & & 5 & 24112015 & 54 & 69 & 15 & 700 \\
\hline & & 6 & 24112015 & 54 & 69 & 15 & 651 \\
\hline & & 7 & 24112015 & 54 & 69 & 15 & 565 \\
\hline & & 8 & 16112015 & 47 & 62 & 15 & 810 \\
\hline \multirow{7}{*}{4} & \multirow{7}{*}{$27 \%$} & 1 & 16112015 & 47 & 63 & 16 & 565 \\
\hline & & 2 & 16112015 & 47 & 62 & 15 & 685 \\
\hline & & 3 & 24112015 & 54 & 71 & 17 & 594 \\
\hline & & 5 & 16112015 & 47 & 62 & 15 & 718 \\
\hline & & 6 & 24112015 & 54 & 69 & 15 & 498 \\
\hline & & 7 & 16112015 & 47 & 63 & 16 & 739 \\
\hline & & 8 & 24112015 & 54 & 54 & 0 & 676 \\
\hline
\end{tabular}




\begin{tabular}{|c|c|c|c|c|c|c|c|}
\hline Beh. & $\begin{array}{c}\text { Aandeel } \\
\text { champost in } \\
\text { substraat }\end{array}$ & 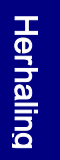 & 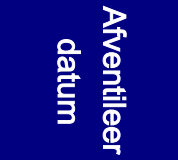 & $\begin{array}{c}\text { \# dagen } \\
\text { substraat } \\
\text { kolonisatie }\end{array}$ & $\begin{array}{c}\text { eerste } \\
\text { oogstdag }\end{array}$ & $\begin{array}{l}\text { \# dagen tussen } \\
\text { afventileren en } \\
\text { eerste oogstdag }\end{array}$ & $\begin{array}{l}\text { Opbrengst } \\
\text { (gram/zak) }\end{array}$ \\
\hline \multirow{8}{*}{5} & \multirow{8}{*}{$18 \%$} & 1 & 9112015 & 40 & 55 & 15 & 611 \\
\hline & & 2 & 16112015 & 47 & 61 & 14 & 792 \\
\hline & & 3 & 9112015 & 40 & 54 & 14 & 732 \\
\hline & & 4 & 9112015 & 40 & 54 & 14 & 703 \\
\hline & & 5 & 16112015 & 47 & 62 & 15 & 840 \\
\hline & & 6 & 16112015 & 47 & 62 & 15 & 801 \\
\hline & & 7 & 9112015 & 40 & 55 & 15 & 608 \\
\hline & & 8 & 9112015 & 40 & 57 & 17 & 503 \\
\hline \multirow{8}{*}{6} & \multirow{8}{*}{$27 \%$} & 1 & 16112015 & 47 & 62 & 15 & 876 \\
\hline & & 2 & 9112015 & 40 & 57 & 17 & 527 \\
\hline & & 3 & 24112015 & 54 & 69 & 15 & 702 \\
\hline & & 4 & 9112015 & 40 & 55 & 15 & 433 \\
\hline & & 5 & 9112015 & 40 & 55 & 15 & 839 \\
\hline & & 6 & 16112015 & 47 & 63 & 16 & 755 \\
\hline & & 7 & 9112015 & 40 & 54 & 14 & 742 \\
\hline & & 8 & 9112015 & 40 & 49 & 9 & 464 \\
\hline \multirow{8}{*}{7} & \multirow{8}{*}{$100 \%$} & 1 & 16112015 & 47 & 63 & 16 & 439 \\
\hline & & 2 & 16112015 & 47 & 63 & 16 & 483 \\
\hline & & 3 & 16112015 & 47 & 63 & 16 & 501 \\
\hline & & 4 & 16112015 & 47 & 63 & 16 & 478 \\
\hline & & 5 & 9112015 & 40 & 57 & 17 & 372 \\
\hline & & 6 & 16112015 & 47 & 63 & 16 & 467 \\
\hline & & 7 & 9112015 & 40 & 57 & 17 & 382 \\
\hline & & 8 & 9112015 & 40 & 57 & 17 & 314 \\
\hline
\end{tabular}

